University of Wyoming College of Law

Law Archive of Wyoming Scholarship

$9-24-2012$

\title{
Competing Stories: A Case Study of the Role of Narrative Reasoning in Judicial Decisions
}

Kenneth D. Chestek

University of Wyoming College of Law, kchestek@uwyo.edu

Follow this and additional works at: https://scholarship.law.uwyo.edu/faculty_articles

\section{Recommended Citation}

Chestek, Kenneth D., "Competing Stories: A Case Study of the Role of Narrative Reasoning in Judicial Decisions" (2012). Faculty Articles. 35.

https://scholarship.law.uwyo.edu/faculty_articles/35

This Article is brought to you for free and open access by the UW College of Law Faculty Scholarship at Law Archive of Wyoming Scholarship. It has been accepted for inclusion in Faculty Articles by an authorized administrator of Law Archive of Wyoming Scholarship. 


\section{Legal Communication \& Rhetoric:JALWD}

Fall 2012 / Volume 9

\section{ARTICLES \& ESSAYS}

\section{Competing Stories:}

A Case Study of the Role of Narrative Reasoning in Judicial Decisions

Kenneth D. Chestek 


\title{
Competing Stories: A Case Study of the Role of Narrative Reasoning in Judicial Decisions
}

\author{
Kenneth D. Chestek*
}

\begin{abstract}
Since 2007, the Applied Legal Storytelling (AppLS) movement has helped scholars understand the role of stories in the legal system. ${ }^{1}$ AppLS ${ }^{2}$ scholarship differs from some of the more-familiar genres of "storytelling" scholarship in that it focuses on the practical: how does storytelling (or "narrative theory") affect what lawyers and judges do in actual cases? ${ }^{3}$

Much, although certainly not all, of this rich body of scholarship examines storytelling from the point of view of the client or the advocate. That is, many scholars are investigating the characteristics of stories and drawing conclusions about how advocates can best take advantage of those characteristics, to tell effective stories on behalf of their clients. ${ }^{4}$
\end{abstract}

\footnotetext{
* ( ) Kenneth D. Chestek 2012. Clinical Professor of Law, Indiana University School of Law-Indianapolis. This article is an elaboration of the author's presentation to the Third Applied Legal Storytelling Conference, Chapter 3: Trailblazing on the Great Divide, held in July, 2011 at the University of Denver-Sturm College of Law. The author wishes to thank Profs. Ruth Anne Robbins, Steve Johansen, Linda Edwards, Linda Berger, and Michael Smith for their helpful comments on early drafts of this work, and my colleagues at IU-Indianapolis, who provided helpful comments following a colloquium while this paper was being conceived. I also wish to thank my research assistant, Naima Solomon, J.D. Candidate in the Class of 2012 from Indiana University School of Law-Indianapolis, for her valuable assistance in the research into the cases I discuss in this paper.
}

1 To date, there have been three international conferences devoted to the topic of Applied Legal Scholarship. The inaugural conference was held in London, England, in July, 2007. It was followed by the "Chapter Two" conference in Portland, Oregon, in July 2009, and "Chapter Three" in Denver, Colorado, in July, 2011. The conference is scheduled to return to London in July, 2013. Papers originally presented at these conferences have been published in many journals, but three peer-reviewed journals have published "proceedings" issues collecting many of the papers presented at these conferences: Volume 41 of The Law Teacher (published by the Association of Law Teachers based in the UK), Volume 14 of Legal Writing: The Journal of the Legal Writing Institute and Volume 7 of The Journal of the Association of Legal Writing Directors. A more complete bibliography of the scholarship that has grown directly out of these conferences is attached as Appendix A.

2 Thanks to Derek Kiernan-Johnson and Ruth Anne Robbins for suggesting this abbreviation.

$\mathbf{3}$ In addition to the articles collected in Appendix A, which grew directly out of the Applied Storytelling conferences, there has been a recent surge in scholarship about in how lawyers use stories to represent clients. See e.g. Dana K. Cole, Psychodrama and the Training of Trial Lawyers: Finding the Story, 21 N. Ill. U. L. Rev. 1 (2001); Brian J. Foley \& Ruth Anne Robbins, Fiction 101: A Primer for Lawyers on How to Use Fiction Writing Techniques to Write Persuasive Fact Sections, 32 Rutgers L. J. 459 (2001); Carolyn Grose, A Persistent Critique: Constructing Clients' Stories, 12 Clinical L. Rev. 329 (2006); Margaret Moore Jackson, Confronting “Unwelcomeness" From the Outside: Using Case Theory to Tell the Stories of SexuallyHarassed Women, 14 Cardozo J. L. \& Gender 61 (2007). The list could go on and on. 
But what is underdeveloped in this discussion so far is a careful consideration of how stories may influence their intended audiences: judges and juries. I broached this subject in 2009 when I conducted a survey of appellate judges and asked them to read a pair of briefs on the same side of a fictional case, one of which limited itself strictly to logosbased reasoning and the second of which made the same logical arguments but included a healthy dose of narrative-based persuasion, principally through providing a great deal more context about how the controversy affected the party filing the brief. I was not surprised to find that a majority of judges and other readers reported that the brief that included the backstory of the case was more persuasive. ${ }^{5}$ While that finding is interesting, however, it does not address several deeper questions: (1) exactly how do stories persuade judges, and (2) is it okay that judges are persuaded by stories?

I believe that it is not only okay that judges pay attention to stories; it is imperative that they do so. However, a thorough examination of that normative issue is beyond the scope of this article. ${ }^{6}$ Instead, this article begins to explore the first question: How do stories work? ${ }^{7}$ In other words, if all parties to any lawsuit follow the advice of the Applied Legal Storytelling scholars and tell effective stories, how might a judge choose between equally effective, but competing, stories?

In keeping with AppLS's focus on practical applications of storytelling, my method in examining this question will be to examine the recent spate of litigation over the Patient Protection and Affordable Care

4 See e.g. Appendix A, infra. Prof. Linda Edwards is one of the exceptions to this trend. She has recently been engaged in a fascinating exploration of how narrative theory informs the law itself, helping to explain how law is created and evolves. See generally Linda H. Edwards, Once Upon a Time in Law: Myth, Metaphor, and Authority, 77 Tenn. L. Rev. 883 (2010) (hereinafter Once Upon a Time); Linda H. Edwards, Presentation, Battle and Betrayal, Tricksters and Champions: the Stories We Tell about Law (Third Applied Legal Storytelling Conference, Denver, Colo., July 10, 2011).

5 See Kenneth D. Chestek, Judging By the Numbers: An Empirical Study of the Power of Story, 7 J. ALWD 1, 18-19 (2010).

6 That examination would require an examination of competing legal philosophies, from the legal positivist on one end of the spectrum to the legal realists on the other and everything in between. For present purposes I will simply posit that narrative reasoning is both legitimate and essential. It is legitimate in the sense that it connects legal decisionmaking to common sense, something that is essential in order for law to retain its legitimacy in society. It is also legitimate in the sense that it is completely normal. People think in stories all the time; it is the principal way humans derive meaning from what they observe. And narrative reasoning is essential because if we deny judges the authority to engage in it, we are asking them to do something unnatural: reason with only half their brains. Indeed, many rules of law (such as balancing tests) actually require judges to engage in narrative reasoning.

For an interesting examination of the legitimate role of emotions in judicial decisionmaking, see Terry A. Mahoney, The Persistent Cultural Script of Judicial Dispassion, 99 Cal. L. Rev. 629, 630-31 (2011) (arguing that "[i]nsistence on emotionless judging ... is a cultural script of unusual longevity and potency," but nevertheless "wrong as a matter of human nature" and not universally shared).

7 I am only "beginning" this inquiry in the sense that I am mostly just seeking evidence that narrative reasoning can be observed in the briefs and opinions filed in the case. If, as I claim, the stories told by the parties had an actual impact on how the judges decided the cases, the mechanism through which this persuasion took place involves a deeper examination of cognitive science principles, which is beyond the scope of this article. 
Act (PPACA $)^{8}$ and to look for evidence in both the parties' briefs and the trial judges' opinions as to whether narrative reasoning was at work.

Shortly after President Obama signed the law, numerous legal challenges were filed by conservative advocacy groups and a large group of Republican state Attorneys General. The central legal issue in the case is whether the law's requirement that individuals purchase health insurance or face a tax penalty exceeds Congress' power under the Commerce Clause. This is a pure question of law, common to every case; yet some trial courts found that Congress did have sufficient power under the Commerce Clause to enact the individual mandate, while others found the mandate exceeded Congress' power. Although the popular press seems to have dismissed the differing results as simply a result of different political leanings by the judges involved, the issue is far more complex. Indeed, since the parties to the lawsuits told different stories in their briefs, it is plausible that the different results might be due at least in part to the different stories told. ${ }^{9}$

Part I of this article briefly reviews some of the foundational principles of narrative theory that are useful in studying the healthcare litigation. Part II sets the stage for the study by describing generally the broad reach of the litigation across the country. Part III takes a look at the trial briefs filed by the parties to the litigation to determine what story they attempted to tell. Although study focuses on the trial court briefs and decisions (because they are a larger data set), the article will occasionally refer to some of the Court of Appeals decisions that have come down as of this writing. I will not attempt to predict the outcome of the pending Supreme Court appeal, since my purpose here is only to examine how narrative may have influenced the trial court judges who had to decide different iterations of essentially the same case.

Part IV then examines the opinions in the major cases and describes how the cases were decided. Finally, Part V considers the possible role that the different narrative choices might have played in reaching different outcomes.

8 Pub. L. No. 111-148, 124 Stat. 119 (2010). Parts of the bill are codified at 42 U.S.C. $\$ \$ 18001$ et seq. (2010); the individual mandate, which is the primary focus of much of this litigation, is codified at 26 U.S.C. $\$ 5000 \mathrm{~A}(2010)$.

9 In this article I am assuming that the merits of the legal rules here (principally the interpretation of the Commerce Clause) are legitimately in dispute and that both sides have sound arguments to advance. My purpose is not to analyze the legal rules but to discern, if possible, the role that narrative reasoning might have played in assisting the courts' decisionmaking in these cases.

In some ways, this study is like kibitzing a duplicate-bridge match: twelve groups are dealt identical hands, but choose different strategies for playing the cards. Some strategies turn out to be more successful than others. Perhaps we can learn some lessons about how the judges in these cases were persuaded by studying those strategies. 


\section{A Brief Introduction to Narrative Reasoning}

"Narrative reasoning" describes the norm-based argument or arguments that motivate a judge to want to rule in a party's favor. ${ }^{10}$ Narrative reasoning is client-centered and very fact-oriented. Narrative reasoning does not supplant the rule-based reason (the law) that allows the court to rule in the client's favor; rather, it provides a reason for the court to want to rule in the client's favor. Professor Richard Neumann calls rule-based arguments "justifying arguments" and norm-based arguments "motivating arguments." 11 If an advocate has both a strong justifying argument and an appealing motivating argument, she is more likely to prevail than if she had only a justifying argument. ${ }^{12}$

One particularly effective type of narrative reasoning is storytelling. ${ }^{13}$ Humans are hard-wired to think in story terms; $;^{14}$ much of what we learn about the world is through our own experience of stories ${ }^{15}$ But this raises the question: What is a "story?" There are many different definitions, of course, but the definition I will use for this exercise is this: "A characterbased and descriptive telling of a character's efforts, over time, to overcome obstacles and achieve a goal."16

This definition identifies three essential elements to any story: characters, goals, and obstacles to overcome. ${ }^{17}$ By comparing how the parties portray their client(s) (the protagonists of the stories they tell), describing

10 See Linda H. Edwards, The Convergence of Analogical and Dialectic Imaginations in Legal Discourse, 20 Legal Studies Forum 7, 11 (1996) (“Narrative reasoning evaluates a litigant's story against cultural narratives and the moral values and themes these narratives encode."). Prof. Chris Rideout describes a similar concept as "narrative rationality" Christopher Rideout, Storytelling, Narrative Rationality, and Legal Persuasion, 14 J. Legal Writing 53 (2008).

11 Richard K. Neumann, Jr., Legal Reasoning and Legal Writing: Structure, Strategy, and Style 309-11 (6th ed., Aspen Publishers 2009).

12 Id. See also Chestek, Judging By the Numbers, supra n. 5, at 4-5. A motivating argument without a complementary justifying argument is doomed to failure; a judge cannot rule in favor of one party because she has a good feeling for that party. The rules of law must also support that party's position.

13 Edwards, Once Upon a Time in Law, supra n. 4, at 886 (citing Jerome Bruner, The Narrative Construction of Reality, 18 Critical Inquiry 1, 4, 10 (1991)).

14 Kendall Haven, Story Proof: the Science Behind the Startling Power of Story 3-4 (Libraries Unlimited 2007) (reporting numerous studies suggesting that humans have told stories to each for 100,000 years and that stories are universal throughout all cultures).
15 The philosopher John Locke expressed it this way: Let us then suppose the mind to be, as we say, white paper void of all characters, without any ideas. How comes it to be furnished? Whence comes it by that vast store which the busy and boundless fancy of man has painted on it with an almost endless variety? Whence has it all the materials of reason and knowledge? To this I answer, in one word, from Experience.

J. Locke, An Essay Concerning Human Understanding, bk. II, chap. 1, 26 (E.P. Dutton 1947). Prof. Michael Smith has pointed out that each of us is a protagonist in our own life story. Michael Smith, Advanced Legal Writing: Theories and Strategies in Persuasive Writing 33 (2d ed., Aspen 2008).

16 This definition is derived from one proposed by storyteller Kendall Haven in his book, Story Proof, supra n. 14, at 79. It has been modified to this formulation by Profs. Ruth Anne Robbins, Steve Johansen, and me for a new legal writing text, forthcoming from Aspen Publishers in 2013.

17 This is, of course, an oversimplification, but for the purpose of analyzing the stories told by the PPACA parties, this simplified structure is sufficient to compare the parties' briefs. For a fuller treatment of how to incorporate a story into a brief, see Ken Chestek, The Plot Thickens: The Appellate Brief as Story, 14 J. Legal Writing 127 (2008). 
the characters'18 goals and showing how they can overcome the obstacles posed by the opposing party, one can discern a useful picture of the story that each party chooses to tell.

\section{A. Describing the protagonist: heroic archetypes}

One useful way of thinking about the protagonist in a client's story is by analyzing heroic archetypes. ${ }^{19}$ Prof. Ruth Anne Robbins suggests that a brief writer should consciously cast her client into the role of "hero" of the story. Studies drawn on the work of Carl Jung, ${ }^{20}$ Joseph Campbell ${ }^{21}$ and others have shown that humans in all cultures (even remote cultures with little or no contact with outsiders), at every time in their history, instinctively recognize and respond to certain archetypal characters. ${ }^{22}$ These characters create something of a standard list of possible protagonists: types of people that most readers will unconsciously understand, identify with, and root for. ${ }^{23}$ Because we innately understand and respond to these hero types, they provide a powerful tool for persuasion.

Heroes, of course, don't all look like Rambo; they come in all shapes and sizes, with different strengths and weaknesses. They can appear as Lovers, Magicians, Innocents, and a wide variety of other types. ${ }^{24} \mathrm{~A}$ careful lawyer will analyze the available choices and make a conscious decision to portray her client as one of these types; by so doing, she can trigger automatic (and unconscious) responses in the judge's mind by creating a mental image of what a story featuring that particular kind of hero probably looks like, and how it is likely to turn out. ${ }^{25}$

\footnotetext{
18 In our definition of "story," the term "character" is meant to refer to the main character in the story: the person (or entity) the storyteller wants the reader to root for. Since this is synonymous with the term "protagonist," I will use the more specific term "protagonist" in referring to the main character in the story (the lawyer's client). Note, however, that most stories have additional characters: antagonists, minor characters, etc.
}

19 Ruth Anne Robbins, Harry Potter, Ruby Slippers and Merlin: Telling the Client's Story Using the Characters and Paradigm of the Archetypal Hero's Journey, 29 Seattle U. L. Rev. 767 (2006).

20 Jung describes a "collective unconscious," made up of archetypes, which humans are born with. "The concept of archetype ... indicates the existence of definite forms in the psyche which seem to be present always and everywhere. Mythological research calls them 'motifs." Carl G. Jung, The Portable Jung 59-60 (Joseph Campbell ed., Penguin Books 1976).

21 See generally Joseph Campbell, The Hero with a Thousand Faces (Princeton U. Press 1949).

22 Robbins, supra n. 19, at 773-74, In particular, "Campbell believed that within all of the world's mythologies there are heroes whose journeys follow a predictable pattern. He opined that the storytellers of the different eras and cultures were trying to tell us, through symbolism and metaphor, of our own journeys towards individuation." Id. at 774.

23 But each of the "heroic" archetypes has a "shadow" side. Just as every hero in literature has a tragic flaw, each type of hero has a tendency toward self-defeating or destructive behavior. See e.g. Dean Miller, The Epic Hero 62 (Johns Hopkins U. Press 2000).

24 Robbins, supra n. 19, at 778-79. The twelve archetypes that Prof. Robbins cites are Warrior, Creator, Caregiver/Martyr, Every person/Orphan, Outlaw/Destroyer, Sage, Explorer/Wanderer/Seeker, Magician, Ruler, Lover, Jester/Fool, and Innocent. Id.

25 Id. at 769. 
Such archetypes have been described as "inner guides" that are present within each of us. ${ }^{26}$ Each of us is on a quest to find meaning and purpose, and each of these archetypes can be invoked at various stages of our lives to assist us on our journey. ${ }^{27}$ Importantly, since these archetypes are innately human, stories that evoke these archetypes resonate with audiences at a subconscious level. If the story describes how one of the heroic archetypes is likely to behave, it will feel true at a "gut" level. Therefore, choosing a plausible heroic archetype to portray the client helps the writer tell a credible story, more likely to resonate with the audience. $^{28}$

\section{B. The hero's journey}

While there are many different types of heroes, all heroes share some features. One such shared characteristic is the hero's quest. ${ }^{29}$ The quest is "a journey we each take to transform ourselves as individuals," or potentially to transform society. ${ }^{30}$ In terms of our definition of story, this equates to the "goal" that each character seeks.

All journeys have three phases: preparation, the journey itself, and the return. ${ }^{31}$ This sequence forms essentially the same arc as the plot of a story: a preexisting state of tranquility (preparation), followed by conflict and efforts to resolve the conflict (the journey). The story ends with either a reinstated or a transformed condition of tranquility (the return). ${ }^{32}$

\section{The obstacle}

The third major part of this definition of a "story" is that the character must struggle to overcome some obstacle. ${ }^{33}$ Though there can be many kinds of potential obstacles, in the context of litigation the obstacle is commonly another person or institution (the opposing party or parties).

26 Carol S. Pearson, Awakening the Heroes Within: Twelve Archetypes to Help Us Find Ourselves and Transform Our World 5-6 (HarperCollins 1991) (cited in Robbins, supra n. 19).

27 Id. at 7-8.

28 For an expansion on some of these heroic archetypes, see infra sec. III.

29 Robbins, supra n. 19, at 790-91; Pearson, supra n. 26, at 3-4.

30 See Robbins, supra n. 19, at 790-91.

31 Pearson, supra n. 26, at 8-12.

32 See Anthony G. Amsterdam \& Jerome Bruner, Minding the Law 113-14 (Harv. U. Press 2000); see also Chestek, Plot Thickens, supra n. 17, at 147.

33 Prof. Robbins sometimes uses the terms "villains" and "dragons" as synonyms to describe the obstacle that the hero must overcome. See e.g. Robbins, supra n. 19, at 786. I will distinguish between these terms. I use the term "dragon" as a broader term encompassing a variety of potential obstacles, including villains, gatekeepers, internal obstacles, and systemic obstacles. A "villain," on the other hand, is a specific type of dragon that embodies pure evil. 
But other possible obstacles could be internal or systemic impediments or failings.

Persons or institutions as obstacles can be thought of as other characters in the story: the antagonist(s). But antagonists come in various forms as well. For example, overzealous counsel may choose to cast the antagonist in the role of the evil Villain. It is tempting to cast one's client's adversary as a purely (or, at least primarily) evil person or institution, with no redeeming characteristics (think Lord Voldemort); indeed, some clients expect lawyers to demonize the opposition in this manner. But purely evil characters are almost entirely fictional; in the real world, almost all defendants have redeeming qualities. Therefore, a more credible role for a defendant-antagonist would be that of a Threshold Guardian (or Gatekeeper). Threshold Guardians are not evil; they just have their own goals, which conflict with those of the protagonist. ${ }^{34}$

But the obstacle need not be an antagonist character at all; the obstacle can instead be internal (such as an addiction, a health issue, or emotional struggles) ${ }^{35}$ or systemic (for example, a legal rule that prevents the protagonist from achieving his or her goal). In short, anything that tends to inhibit the protagonist from achieving his or her goal can be characterized as an obstacle.

A visual depiction of the possible obstacles a protagonist might face is shown in the sidebar "Obstacle Types."

All of these concepts will become useful in analyzing the stories told by the various parties to the PPACA litigation.

\section{Obstacle Types}

Antagonist (another character or characters who oppose the hero)

- Villains (characters who oppose the hero out of animus or an evil nature)

- Threshold Guardians (characters who are not evil but who simply have different goals which impede the hero's quest)

Internal obstacle (such as addiction, physical or mental health issues, emotional struggles, etc.)

Systemic obstacle (such as structure of society or social norms, unfavorable legal

\section{The Major Challenges to the PPACA: Choosing Cases with Stories to Tell}

The PPACA ${ }^{36}$ is highly complex and lengthy. It attempts to implement a comprehensive reform of the way healthcare services are provided to Americans, including specific efforts to provide healthcare insurance to 
many currently uninsured citizens. The bill does many things, ${ }^{37}$ but the most controversial provision is a requirement that most individuals (with limited exceptions for certain people with religious objections or financial hardship) purchase health insurance or pay a tax penalty if they choose not to do so (the "individual mandate"). ${ }^{38}$ The law was challenged immediately in numerous lawsuits around the country. At least one suit was filed before President Obama even signed the law, ${ }^{39}$ while several others were filed the day he signed the law. ${ }^{40}$

I examined all of the PPACA cases to date to determine what story (or stories) the parties were telling. I chose to study the trial court opinions in the major cases challenging the law, partly because at the trial level the facts of the case are most fluid, and in theory storytelling would seem to have the most room to work. ${ }^{41}$ But I also chose to study the trial court opinions in order to have a larger data set, since there are simply more cases at that level than at the appellate level. However, as of the time this article was completed, seven of the twelve cases I studied had been reviewed by different United States Courts of Appeals; ${ }^{42}$ I will refer to some of those appellate decisions from time to time throughout the Article.

My initial review of cases involving some form of challenge to PPACA turned up sixteen reported decisions. Of these, I discarded several from the data set as not being serious challenges to the statute. ${ }^{43}$ Other cases

37 The law amends numerous previous Acts of Congress, most notably the Public Service Health Act, the Social Security Act, and the Internal Revenue Code. Among the most important provisions of the Act are a prohibition of insurance companies rejecting applicants because of preexisting medical conditions; creation of "health insurance exchanges" in every state to assist individuals and employers in purchasing insurance and comparing rates; a requirement for certain employers to provide health care insurance to its employees or pay a tax penalty if it chooses not to (the "employer mandate"); and the "individual mandate" requiring people who are not covered by employer plans to acquire health insurance. See id.

3826 U.S.C. $\$ 5000$ A (2010).

39 The bill was signed on March 23, 2010. Orly Taitz filed an amended complaint in her pending lawsuit challenging President Obama's qualifications for office on March 22, 2010, adding the claim that Obama would not have authority to sign PPACA into law since he could not prove he was legally entitled to hold the office of President. See Pl's 1st Amend. Compl., Taitz v. Obama, 2010 WL 1859343 (D.D.C. March 22, 2010). This case was ultimately dismissed by the trial court and was not included in this study.

40 See e.g. Liberty University v. Geithner, 753 F. Supp. 2d 611 (W.D. Va. 2010); Virginia ex rel. Cuccinelli v. Sebelius, 728 F. Supp. 2d 768 (E.D. Va. 2010); Florida ex rel. Bondi v. U.S. Dept. of Health and Human Services, 780 F. Supp. 2d 1256 (N.D. Fla. 2011). The district court in Florida ex rel. Bondi noted that " $\mathrm{t}]$ his case, challenging the Constitutionality of the Act, was filed minutes after the President signed [it]". 780 F. Supp. 2d at 1263.

41 Of course, storytelling can be effective at the appellate level as well, as I have argued elsewhere. See Chestek, The Plot Thickens, supra n. 17; Chestek, Judging By the Numbers, supra n. 5. Many other scholars also focus on appellate briefs and the stories they tell; see, e.g., Edwards, Once Upon a Time, supra n. 4, at 885; Helen A. Anderson, Changing Fashions in Advocacy: 100 Years of Brief-Writing Advice, 11 J. App. Prac. \& Process 1 (2010).

42 Four Courts of Appeals affirmed the trial court decisions.: Florida ex rel. Atty. Gen. v. U.S. Dept. of Health and Human Services, 648 F.3d 1235 (11th Cir. 2011); N. J. Phys., Inc. v. Obama, 653 F.3d 234 (3d Cir. 2011); Thomas More Law Ctr. v. Obama, 651 F.3d 529 (6th Cir. 2011); Liberty University v. Geithner, 671 F.3d 391 (4th Cir. Sept. 8, 2011). One case was vacated and remanded to the trial court. Virginia ex rel. Cuccinelli v. Sebelius, 656 F.3d 253 (4th Cir. 2011). The United States Supreme Court has granted certiorari in another case. U.S. Dept. of Health and Human Services v. Florida, __ U.S. _, 132 S. Ct. 604 (2011). The decision in that case is likely to be filed shortly before this Article appears in print. 
involved limited challenges to specific parts of the statute and not a facial attack on the entire statute, ${ }^{44}$ or had not yet been decided on the merits. I ended up with twelve cases that made facial challenges to the statute and that had resulted in some significant decision by a trial judge.

The issues raised by these cases vary. In reading the briefs, I counted at least nineteen separate issues raised by at least one litigant. Most of these involved different legal theories raised by the plaintiffs, ranging from claims that PPACA exceeded the powers of Congress to regulate interstate commerce, to substantive due process issues, separation of powers claims, and several claims of infringement of religious liberty under the First Amendment. For its part, the United States commonly raised at least three defensive issues: (1) that the plaintiffs lacked a particularized, certain injury and therefore lacked standing to sue; (2) that the statute did not go completely into effect until 2014, and the claim was therefore unripe; and (3) that the individual mandate was enforced by a tax provision, so the suits were barred by the Anti-Injunction Act. ${ }^{45}$

In almost every case, the defendants filed motions to dismiss based on the three defenses listed. No trial court ruled in favor of the government on either the ripeness or the Anti-Injunction Act issues. ${ }^{46}$ However, the courts reached different results on the standing issue, so it became interesting to study the twelve cases to see why this occurred.

In addition, six cases that resolved the standing issue in favor of the plaintiffs went on to address the substantive Commerce Clause issue. These cases also split, with three cases finding that the statute was a valid exercise of Congress' power under that clause, and three finding the statute unconstitutional under that clause. ${ }^{47}$

Since the standing and Commerce Clause issues were the only issues common to all twelve major cases, I decided to study those cases to see if I could discern any patterns in the stories the parties told, or the rationales used by the courts in their decisions. The twelve cases are summarized in Table 1; they will be discussed in more detail on the next page.

\footnotetext{
43 As noted in n. 42, supra, the first case to challenge the law was based on a theory that since President Obama could not prove that he was actually born in the United States, he did not have legitimate authority to sign the bill into law. Taitz $v$. Obama, 707 F. Supp. 2d 1. Also, a group of physicians challenged the law on the basis of alleged ultra vires conduct by President Obama in "coercing" Sen. Ben Nelson to vote in favor of the bill, violating the doctrine of separation of powers. Anderson v. Obama, 2010 WL 3000765 (D. Md. 2010). Both of these cases were quickly dismissed by the courts, and not considered in this study.
}

44 See e.g. Phys. Hosp. of America v. Sebelius, 707 F. Supp. 2d 828 (E.D. Tex. 2011).

4526 U.S.C. $\$ 7421$ (2006).

46 However, the Fourth Circuit did find the Anti-Injunction Act argument persuasive and upheld the dismissal of one of the private party lawsuits on that basis, even though the trial court had not ruled on that issue. Liberty University v. Geithner, 671 F.3d at 401-15.

47 Since these are the only cases that reached the substantive Commerce Clause issue, they are the cases that have received of the mainstream media attention. 
Table 1: List of PPACA Cases, Trial Judges, and Results

(As of December 2011)

$\begin{array}{ccccccc}\text { Case } & \begin{array}{c}\text { Date of } \\ \text { Trial Court } \\ \text { Decision }\end{array} & \begin{array}{c}\text { Trial } \\ \text { Judge }\end{array} & \begin{array}{c}\text { App'ting } \\ \text { President }\end{array} & \begin{array}{c}\text { Trial } \\ \text { Result }\end{array} & \begin{array}{c}\text { Result } \\ \text { on Appeal }\end{array} \begin{array}{c}\text { Date of } \\ \text { Appellate } \\ \text { Decision }\end{array}\end{array}$

Cases Decided on Standing Issue (in chronological order)

$\begin{array}{lcccccc}\text { Baldwin v. } & \text { Aug. 27, } & \text { Dana } & \text { G.W. } & \text { No } & \text { Aff'd 654 } & \text { Aug. 12, } \\ \text { Sebelius, 2010 } & 2010 & \text { Sabraw } & \text { Bush } & \text { Standing } & \text { F.3d } 877 & 2011 \\ \text { WL 3418436 } & & & & & & \end{array}$

(S.D. Cal. 2010)

\begin{tabular}{|c|c|c|c|c|}
\hline $\begin{array}{l}\text { Shreeve } v \text {. } \\
\text { Obama, } 2010\end{array}$ & $\begin{array}{l}\text { Nov. 4, } \\
2010\end{array}$ & $\begin{array}{l}\text { Curtis } \\
\text { Collier }\end{array}$ & Clinton & $\begin{array}{c}\text { No } \\
\text { Standing }\end{array}$ \\
\hline
\end{tabular}

(E.D. Tenn 2010)

$\begin{array}{lcccccc}\text { N.J. Phys. Assoc } & \text { Dec. } 8 & \text { Susan } & \text { G.W. } & \text { No } & \text { Aff'd } 653 & \text { Aug. 3, } \\ \begin{array}{l}\text { V. Obama, } \\ \text { 757 F. Supp. }\end{array} & 2010 & \text { Wigenton } & \text { Bush } & \text { Standing } & \begin{array}{c}\text { F.3d 234 } \\ \text { (3d Cir. 2011) }\end{array} & \end{array}$

2d 502 (D. N.J. 2010)

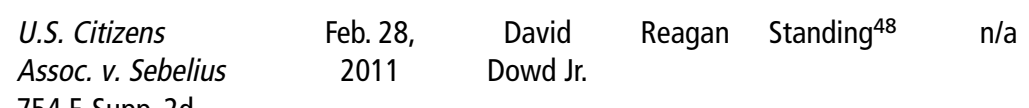

754 F. Supp. 2d

903 (N.D. Ohio 2011)

Bryant v. Holder

809 F. Supp. 2d 563

(S.D. Miss. 2011) ${ }^{49}$

Butler v. Obama

814 F. Supp. 2d 230

$\begin{array}{ccc}\text { Aug. 29, } & \text { Keith } & \text { G.W. } \\ 2011 & \text { Starrett } & \text { Bush }\end{array}$

Standing

$\mathrm{n} / \mathrm{a}$

(E.D. N.Y. 2011)

$\begin{array}{ccccc}\text { Sept. 30, } & \begin{array}{c}\text { Joseph F. } \\ \text { Bianco }\end{array} & \begin{array}{c}\text { G.W. } \\ \text { Bush }\end{array} & \text { No } & \text { n/a }\end{array}$

Cases Decided on Commerce Clause Issue (in chronological order) ${ }^{50}$

\begin{tabular}{|c|c|c|c|c|c|c|}
\hline $\begin{array}{l}\text { Thomas More } \\
\text { Ctr. v. Obama, } \\
720 \text { F. Supp. 2d } 882 \\
\text { (E.D. Mich 2010) }\end{array}$ & $\begin{array}{l}\text { Oct. 7, } \\
2010\end{array}$ & $\begin{array}{l}\text { George C. } \\
\text { Steeh }\end{array}$ & Clinton & $\begin{array}{l}\text { Consti- } \\
\text { tutional }\end{array}$ & $\begin{array}{c}\text { Aff'd } 651 \\
\text { F.3d } 529 \\
\text { (6th Cir. 2011) }\end{array}$ & $\begin{array}{c}\text { June 11, } \\
2011\end{array}$ \\
\hline $\begin{array}{l}\text { Liberty University } \\
\text { v. Geithner, } 753 \mathrm{~F} . \\
\text { Supp. } 2 \mathrm{~d} 611\end{array}$ & $\begin{array}{c}\text { Nov. 30, } \\
2010\end{array}$ & $\begin{array}{c}\text { Norman K. } \\
\text { Moon }\end{array}$ & Clinton & $\begin{array}{l}\text { Consti- } \\
\text { tutional }\end{array}$ & $\begin{array}{c}\text { Vacated,2011 } \\
\text { WL 3962915 } \\
(4 \text { th Cir. 2011) }\end{array}$ & $\begin{array}{l}\text { Sept. } 8 \\
2011\end{array}$ \\
\hline
\end{tabular}

(W.D. Va. 2010)

48 On July 1, 2011, Judge Dowd granted summary judgment to the United States on the Commerce Clause issue on basis of Thomas More Ctr. v. Obama, 651 F.3d 529 (6th Circuit 2011). Since the judge did no more than note that the Sixth Circuit opinion was binding authority and engaged in no further analysis, I have left this case in the category of "cases decided on standing issue."

49 The court initially dismissed the Plaintiffs' complaint for lack of standing. Bryant v. Holder, 2011 WL 710693 (E.D. N.Y. Feb. 3, 2011). However, the court gave Plaintiffs leave to amend their complaint, and later found that their Second Amended Petition did allege a sufficiently particularized and certain injury to confer standing on the Plaintiffs to maintain their cause of action. 


\begin{tabular}{|c|c|c|c|c|c|c|}
\hline $\begin{array}{l}\text { Virginia ex rel } \\
\text { Cuccinelli v. Sebelious } \\
728 \text { F. Supp. 2d } 768 \\
\text { (E.D. Va. 2010) }\end{array}$ & $\begin{array}{c}\text { Dec. 13, } \\
2010\end{array}$ & $\begin{array}{l}\text { Henry } \\
\text { Hudson }\end{array}$ & $\begin{array}{l}\text { G.W. } \\
\text { Bush }\end{array}$ & $\begin{array}{l}\text { Unconsti- } \\
\text { tutional }\end{array}$ & $\begin{array}{c}\text { Vacated, } 656 \\
\text { F.3d } 253 \\
(4 \text { th Cir. 2011) } \\
\text { (52 }\end{array}$ & $\begin{array}{c}\text { Sept. 8, } \\
2011\end{array}$ \\
\hline $\begin{array}{l}\text { Florida ex rel. Bondi } \\
\text { v. Sebelius, } 780 \text { F. Supp. } \\
\text { 2d } 1256 \text { (N.D. Fla. 2011) }\end{array}$ & $\begin{array}{c}\text { Jan. 31, } \\
2011\end{array}$ & $\begin{array}{l}\text { Roger } \\
\text { Vinson }\end{array}$ & Reagan & $\begin{array}{l}\text { Unconsti- } \\
\text { tutional }\end{array}$ & $\begin{array}{c}\text { Aff'd, } 648 \\
\text { F.3d 1235 } \\
\text { (11th Cir. 2011) }\end{array}$ & $\begin{array}{c}\text { Aug. 12, } \\
2011\end{array}$ \\
\hline $\begin{array}{l}\text { Mead v. Holder } \\
766 \text { F. Supp. 2d } 16 \\
\text { (D. DC 2011) }\end{array}$ & $\begin{array}{c}\text { Feb .22, } \\
2011\end{array}$ & $\begin{array}{l}\text { Gladys } \\
\text { Kessler }\end{array}$ & Clinton & $\begin{array}{l}\text { Consti- } \\
\text { utional }\end{array}$ & $\begin{array}{l}\text { Aff'd sub nom } \\
\text { Seven-Sky v. } \\
\text { Holder, } 661 \mathrm{~F} . \\
\text { 3d } 1 \text { (D. DC 2011) }\end{array}$ & $\begin{array}{c}\text { Nov. 8, } \\
2011\end{array}$ \\
\hline
\end{tabular}

$\begin{array}{lccccc}\text { Goudy-Bachman v. } & \text { Sept. 13, } & \text { Chrisopher } & \text { G.W. } & \text { Unconsti- } & \text { n/a } \\ \text { U.S. Dept. of Health } & 2011 & \text { Conner } & \text { Bush } & \text { tutional } & \end{array}$

\title{
III. Telling the Clients' Stories
}

\begin{abstract}
Since stories require protagonists, the first thing I did in examining the twelve cases was to see whether there were commonalities among the plaintiffs. The plaintiffs could be grouped into three main categories: (1) private individuals (health-care consumers) and their employers, ${ }^{53}$ (2) physicians and advocacy groups for physicians, ${ }^{54}$ and (3) state governments. ${ }^{55}$ The defendants varied from case to case, but generally
\end{abstract}

\footnotetext{
50 The six cases listed in Table 1 that were resolved on the basis of the Commerce Clause reveal a pattern that some in the media have latched on to as an "explanation" for why they reached different results: the three cases ruling that the law was constitutional were decided by judges appointed by Democratic Presidents, while the three cases which ruled the law unconstitutional were decided by judges appointed by Republican Presidents. Actually, the mainstream media focused on just the first five cases on the list, since they were all decided before the various Courts of Appeal began resolving the appeals. The sixth case on the list, Goudy-Bachman v. U.S. Dept. of Health and Human Services, was not decided until September 13, 2011, after three different Courts of Appeal had ruled. Accordingly, that case received very little media attention when it was decided. It does, however, follow the supposed "pattern" of judges' political party bias. Regardless of basis, the political bias explanation is superficial and almost certainly incomplete. See infra n. 115 and accompanying text.
}

51 The court vacated and remanded the case to the trial court on basis that Anti-Injunction Act barred any enforcement prior to the levy of the tax designed to enforce the provisions of PPACA.

52 The court vacated and remanded the case to the trial court on the basis that the Commonwealth of Virginia lacked standing to challenge the individual mandate of the law.

53 This is the largest group, and includes nine of the twelve cases in the study: Baldwin v. Sebelius, 2010 WL 3418436 (S.D. Cal. 2010); Shreeve v. Obama, 2010 WL 4628177 (E.D. Tenn. 2010); Goudy-Bachman v. U.S. Dept. of Health and Human Services, 764 F. Supp. 2d 684 (M.D. Pa. 2011); Bryant v. Holder, 809 F. Supp. 2d 563 (S.D. Miss. 2011); U.S. Citizens Assoc. v. Sebelius, 754 F. Supp. 2d 903 (N.D. Ohio 2010); Thomas More Law Ctr v. Obama, 720 F. Supp. 2d 882 (E.D. Mich 2010), aff'd 651 F.3d 529 (6th Cir. 2011); Liberty University v. Geithner, 753 F. Supp. 2d 611 (W.D. Va. 2010); Mead v. Holder, 766 F. Supp. 2d 16 (D. D.C. 2011); and Butler v. Obama, 814 F. Supp. 2d 230 (E.D. N.Y. 2011).

54 The only case in the study group filed by a group of physicians is N.J. Phys. Assoc. v. Obama. Another case filed by a group of physicians was excluded from the study since it made an as applied claim against only a portion of the statute relating to billing procedures for physicians: Phys. Hosp. of America v. Sebelius.

55 This group includes two cases: Virginia ex rel. Cuccinelli v. Sebelius and Florida ex rel. Bondi v. U.S. Dept. Of Health and Human Services. The latter case includes twenty-six states, through their Attorneys General (all Republican), as well as a few individuals, as plaintiffs. 
included the United States Department of Health and Human Services; its Secretary, Kathleen Sebelius; Treasury Secretary Timothy Geithner (because the enforcement mechanism for the individual mandate is a tax penalty); and in a few cases, President Barrack Obama. Yet this group of defendants told a unified story, since in most of the cases that reached the Commerce Clause issue, and most of the cases that ended with rulings on the standing issue only, a core group of attorneys from the Justice Department collaborated on the briefs. ${ }^{56}$

The stories told by each group of plaintiffs are counterpoised below to that told by the United States. For each, the brief champions a particular protagonist and presents that protagonist's goal and the obstacles (antagonists, systemic, or other) preventing the protagonist from achieving that goal. Each protagonist corresponds to a heroic archetype. Comparing the three different plaintiff stories to the defendants' story may help explain why the cases reached different results.

\section{A. Physician stories}

Only one case in the study group was filed by physicians. It can be summarized in the sidebar "Physician Stories."

\section{Protagonist}

The first task in examining a narrative is to determine who the protagonist is. What character or institution does the author want us to root for? It is not always obvious.

In this case, the caption of the complaint lists, in order, the New Jersey Physicians, Inc. (described in the principal brief as "a

\section{Physician Stories}

Protagonist(s) Physicians' association, an individual physician, and a patient of that physician. Heroic type: Outlaw

Goal(s) To preserve the existing business model of patients contracting directly with physicians and not dealing with insurance companies

Obstacle(s) (1) Systemic (individual mandate of PPACA); (2) Antagonist (Congress as Villain) physicians' advocacy organization), Dr. Mario

A. Criscito (an individual physician), and "Patient Roe." Little detail is provided as to Patient Roe's identity, much less his objective. The plaintiffs' brief says only that "[t]he mandate [of the law] will force him to have qualifying health insurance, even though he does not have it and does not want it. Thus, he will be forced to enter into a transaction he does not want, or face monetary penalties." 57 The brief does a better job explaining what the physicians object to: the Act "will have a direct, substantial

56 In the cases for which briefs are available on Westlaw, three attorneys signed on behalf of the government in all of the cases decided on the Commerce Clause issue as well as in most of the briefs decided on standing: Assistant Attorney General Tony West, Deputy Assistant Attorney General Ian Heath Gershengorn, and Sheila Lieber. Attorney Jennifer Rivera also signed most of the briefs. Briefs were not available on Westlaw for all of the cases resolved on the standing issue. 
impact upon Dr. Criscito's medical practice, the manner in which he may, or may not, seek payment for his professional services and the manner in which he may render treatment to his patients." 58 As for the physician's organization, it "seeks to protect[] the professional and economic interests of it[s] physician members and, indeed, all of New Jersey's physicians, are germane to New Jersey Physicians' purpose as a physician advocacy organization." 59 It also claims that "Dr. Criscito, and many of New Jersey Physicians' members, accept direct payments from patients, and will not be able to do so once the mandate goes into effect." ${ }^{60}$ However, it does not cite any provision of the Act which so holds. ${ }^{61}$

Since the physicians' organization and Dr. Criscito's goals are described more fully, one is left with the impression that main protagonists in the case are the physicians; the anonymous plaintiff is probably included as a hedge to insure that somebody in the case has standing. As such, Patient Roe is relegated essentially to the role of a helper, or "companion;" 62 the story is really about the physicians' struggle to preserve the existing business model for the practice of medicine.

\section{Goal}

Having identified the principal protagonist in the story, identifying the heroic archetype that the advocates choose for their clients can help us determine how the stories of the different parties might be viewed by the reader-the court. Identifying the archetype can be tricky, however, since many of the twelve types seem to overlap. One way of distinguishing between heroic archetypes is to examine the protagonist's quest, or goal.

In the case of the physicians, two likely heroic archetypes might apply: the Warrior and the Outlaw. A Warrior's quest is to "fight ... for just causes/important issue." 63 A Warrior's quest is thus externally oriented; he fights for a principle because it helps others. An Outlaw's quest, by contrast, is more self-interested; he seeks to destroy what he perceives as not working, or that which interferes with his personal autonomy. ${ }^{64}$

61 Probably because the Act says no such thing. See text accompanying note X, infra.

62 See Robbins, supra n. 19, at 790 (describing the role of the companion).

$63 \mathrm{Id}$. at 802 .

64 Pearson's term for "Outlaw" hero is a "Destroyer" hero. See Pearson, supra n. 26, at 136. She says this type of hero is often evoked within each of us "by a sense of powerlessness, the discovery that everything you have counted on, worked toward, or tried to build in life has come to nothing. It can be an encounter with injustice. You have been good, disciplined, hardworking, and loving, and in return you get kicked in the teeth." Id. at 136-37. It is not hard to imagine the plaintiffs in this case believing themselves to having been "kicked in the teeth" by what they perceive as an unjust intrusion into their private affairs by the government, thus calling forth the Destroyer (Outlaw) hero within them. 
Given the essentially self-interested nature of the physicians' quest, the most logical heroic type that describes the physicians is an Outlaw hero. In the protagonists' eyes, "what is not working" is the law itself, since it allegedly prevents them from pursuing their preferred method of doing business. A quest of allowing physicians to continue to make lots of money by preserving the existing business model is not externally oriented (i.e., the quest helps the protagonists themselves, not others), so the Warrior archetype does not seem to fit.

\section{Obstacle}

Several obstacles are possible in this story. The obvious obstacle is a systemic one: the PPACA itself. And, indeed, the physicians' brief does attack the statute on its face. But the plaintiffs are not content to simply attack the statute. Instead, the brief includes some very broad attacks on Congress itself. ${ }^{65}$ The sometimes hyperbolic rhetoric ${ }^{66}$ leads one to conclude that Congress is purely evil: a quintessential Villain.

\section{B. The private individuals and employers' story}

Since there were eight different cases in this category, it is somewhat difficult to generalize about the stories told by the private individuals and employers. But the plaintiffs' briefs in the three privateindividual cases decided on the Commerce Clause issue told a pretty
Individual and Employer Stories

Protagonist(s) Mostly private individuals, plus a few private employers and a public interest law firm. Heroic type: Outlaw

Goal(s) Individual plaintiffs don't have insurance, don't qualify for a religious exception or for financial assistance to purchase insurance, and don't want to have to buy insurance.

Obstacle(s) (1) Systemic (individual mandate of PPACA); (2) Antagonist (Congress as Villain)

65 For example, in asserting that the PPACA is outside of the reach of Congress' power under the Commerce Clause, the plaintiffs write,

Of course, the defendants' reasoning could be used to support any exercise of Congressional power, at all, no matter how far-reaching or attenuated, as long as one could posit a link between a governmental interest and some form of economic activity (or inactivity). For example, Congress could deem the viability of the American automobile industry essential to the economic health of the nation, particularly as the federal government now owns a sixty-one percent interest in General Motors. In order to assure its viability, Congress could mandate that every citizen (other than those who could show some sort of "economic hardship" purchase a new General Motors automobile every five years, and, again employing this "logic," even mandate which model automobile those individuals had to buy.

Pl. Brief in Opposition to Def. Mot. to Dismiss, N.J. Phys., Inc. v. Obama, 2010 WL 4597787, at 12 (footnote omitted).

66 The Plaintiffs claim that individuals who choose not to purchase health insurance are not engaged in "commerce," so Congress has no power to compel them to engage in a commercial transaction. Although that position has some logical merit, plaintiffs resort to mockery in defending their position:

A decision to do nothing does not convert nothing to something. Zero multiplied by any number still equals zero. Under Defendants' logic, any failure to buy - or sell - particular goods or services is both a regulable prelude to future economic activity and a decision Congress can reach because it impacts the existing marketplace. Indeed, thought, by itself, would be reachable under this tortured logic.

Id. at 14 . 


\section{consistent story, which is summarized in the sidebar "Individual and Employer Stories."}

\section{Protagonist}

In two of the three Commerce Clause cases in this group, the first-named plaintiff is an institution or employer, joined by a number of private individuals; ${ }^{67}$ the third case was brought only by private individuals. ${ }^{68}$ But even the two cases in which an institution is the lead plaintiff, the briefs filed by the parties focus heavily on the law's alleged impact on the individual plaintiffs. Thus, the principal protagonists in these cases appear to be individuals who prefer not to purchase health insurance. They are generally portrayed as "rugged individuals," distrustful of government almost to the point of being hermits, eccentrics, or religious zealots. ${ }^{69}$ Their refusal to purchase insurance is not clearly explained in any of the briefs; ${ }^{70}$ thus, the protagonists' goal appears simply to be left alone.

67 In Liberty University v. Geithner, the lead plaintiff is a private Christian university founded by the Rev. Jerry Falwell Sr. In Thomas More Law Ctr. v. Obama, the lead plaintiff describes itself as "a national, public interest law firm based in Ann Arbor, Michigan." Cmpl. 10, 2010 WL 4784409 (E.D. Mich. March 23, 2010). It also alleges that it provides healthcare coverage to its employees, and therefore is subject to the provisions of the PPACA. Id. at 12. These are the only two parties in this group of cases which claim standing as employers affected by PPACA. Both cases also include a number of individuals as coplaintiffs.

68 Mead v. Holder, 766 F. Supp. 2d at 18 (listing plaintiffs).

69 For example, the government, and one judge, noted that President Obama had signed an executive order confirming that no federal funding could be used to fund abortions, in conformity with the preexisting Hyde Amendment. They noted, as well, that provisions of PPACA itself require at least one multistate health insurance plan that does not provide coverage for abortion services except in cases of rape or incest or when the life of the woman is endangered. See Pub. L. No. 111-148, $\mathbb{S}$ 1334(a)(6); Liberty University v. Geithner, 753 F. Supp. 2d at 643. In light of the specific provisions of the law protecting against the possible involvement of federal funds with abortion services and requiring at least one insurance plan for individuals to choose that did not cover those services (other than situations in which courts have held that a woman's right of access to those services may not be prohibited), plaintiffs' objections along these lines appear somewhat unreasonable.

70 In Liberty University v. Geithner, the Plaintiffs' brief reports that two of the individual plaintiffs

have chosen not to purchase health insurance and do not desire health insurance coverage, but instead take care of health care costs as they arise. They are Christians who believe in living out their sincerely held religious beliefs in everyday life, including in the lifestyle choice they make. [They] have sincerely held religious beliefs that abortions, except where necessary to save the life of the pregnant mother, are murder and morally repugnant, that they should play no part in facilitating, subsidizing, easing, funding, or supporting such abortions because to do so is evil and morally repugnant complicity, and that they should not formally associate with those who would facilitate, subsidize, ease, fund or support such abortions.

Pl. Brief in Opposition to Mot. to Dismiss, 2010 WL 4850338 at 7 (W.D. Va. Sept. 3, 2010). How PPACA might "facilitate, subsidize, ease, fund or support" abortions is not explained.

Likewise, in Thomas More Law Ctr. v. Obama,

Plaintiffs do not have private health care insurance. They do not intend to purchase health care coverage. And they object to being forced to purchase health care coverage under the Act... . Plaintiffs have arranged their personal affairs such that it will be a hardship for them to have to either pay for health insurance that is not necessary or desirable or face penalties under the Act.... [They will have to reorganize their affairs and essentially change the way they presently live to meet the government's demands.

Pl. Mot. for a Prelim. Inj. \& Brief in Support, 2010 WL 4784264 at 4 (E.D. Mich., April 6, 2010). And the plaintiffs' goals are no clearer in Mead v. Holder: "Plaintiffs are United States citizens who do not currently have health insurance and do not want or need such insurance." Memo. of Points and Authorities in Support of Pl. Mot. for S.J., 2010 WL 5827945 at 7 (D. D.C., August 10, 2010). 
At least three potential heroic archetypes might fit the individual plaintiffs in this group of cases. They could be viewed as Seekers-Wanderers, whose archetypal task is to seek a better life through exploration of the world. ${ }^{71}$ The chief virtue of such heroes is autonomy; their fear is conformity. ${ }^{72}$ But Wanderers defeat their dragons by walking away from them, not by doing battle with them; ${ }^{73}$ and the briefs filed on behalf of these plaintiffs are full of fight. Thus, much like the physician plaintiffs in the previous group, the more likely choices of heroic archetype for the private individuals are Warrior or Outlaw. Choosing the Warrior hero is tempting, because unlike the physicians, whose quest was simply to retain their economic advantage in the practice of medicine, the goal of these plaintiffs-autonomy and self-determination-seems appealing. But, ultimately, the Outlaw archetype seems to be the more likely choice, for the briefs are full of "righteous indignation" and claims of "radical freedoms," two of the hallmark virtues of Outlaw heroes, ${ }^{74}$ and the protagonists' goals seem highly self-interested, that is, to protect their autonomy.

\section{Goal}

The goal of this group of plaintiffs is unambiguously identified as protecting their right to decline to purchase health insurance. But rather than set forth a vision of individual freedom, the briefs focus on the obstacle: Congress' assertion of broad powers under the Commerce Clause. Little space is devoted to why individual freedom is important to the protagonist. The overall impression the briefs leave with the reader is that of stubbornness: Congress cannot force the plaintiffs to behave in ways that pleases Congress. By simply asserting that they prefer not to abide by the law, the plaintiffs overtly don the clothing of the Outlaw, seeking to destroy the law they perceive as impinging on their freedom.

\section{Obstacle}

The private individuals and employers also seem to share the same obstacles as the physician plaintiffs: the PPACA itself is a systemic obstacle, while Congress is the antagonist. But not all the plaintiffs seemed to cast Congress in the role of Villain. The plaintiffs' brief in Mead v. Holder $^{75}$ seems a bit more focused on logical reasoning and is less hyperbolic, suggesting that Congress is merely a Threshold Guardian.

71 See Robbins, supra n. 19, at 803; Pearson, supra n. 26, at 123-25.

72 Robbins, supra n. 19 at 803.

73 Pearson, supra n. 26, at 123.

74 See Robbins, supra n. 19, at 802.

75 See Memo. of Points and Authorities in Support of Pl. Mot. for S.J., 2010 WL 5827945. 


\title{
However, the briefs in Thomas More Law Ctr. v. Obama and Liberty University v. Geithner tend to demonize Congress. ${ }^{76}$ For example, Thomas More Law Center's brief contains this parade-of-horribles argument:
}

\begin{abstract}
If the Act is understood to fall within Congress' Commerce Clause authority, the federal government will have the absolute and unfettered power to create complex regulatory schemes to fix every perceived problem imaginable and to do so by ordering private citizens to engage in affirmative acts, under penalty of law, such as taking vitamins, losing weight, joining health clubs, buying a GMC truck, or purchasing an AIG insurance policy, among others. The term "Nanny State" does not even begin to describe what we will have wrought if in fact the Health Care Reform Act falls within any imaginable governmental authority. To be sure, George Orwell's 1984 will be just the primer for our new civics. ${ }^{77}$
\end{abstract}

Liberty University's brief contains additional examples of namecalling and hyperbolic rhetoric. ${ }^{78}$

It is therefore safe to say that at least some of these plaintiffs attempted, like the physicians, to cast Congress in the role of Villain: purely evil.

\section{The state-government story}

Of the twelve cases in my study, only two were filed by state governments or their representatives. ${ }^{79}$ Both cases were resolved on the merits of the

76 See Pl. Mot. for Prelim. Inj. \& Brief in Support, Thomas More Law Ctr. v. Obama, 2010 WL 4784264; Pl. Brief in Opposition to Mot. to Dismiss, Liberty University v. Geithner, 2010 WL 4850338.

I realize that this statement is highly subjective. In an effort to quantify this claim, I engaged in a little experiment, based on the article by Professors Lance Long and William Christensen: Clearly, Using Intensifiers is Very Bad-Or Is It?, 45 Idaho L. Rev. 171 (2008). In that article, Professors Long and Christensen counted the number of times "intensifiers" (words like "clearly," "plainly," "very," "obviously" and the like appeared on the pages of actual briefs filed in the Utah Supreme Court. They then calculated the "intensifiers per page ratio" for each brief, then studied the results in those cases to see if there was any correlation between using intensifiers and success (or failure) in the outcome. I borrowed their methodology and designed a WordPerfect macro to "read" all of the briefs in these cases and count the number of times certain intensifiers appeared in the briefs. I used Long and Christensen's list of intensifiers, plus a few variations and additions of words that I considered to be hyperbole, then manually checked to be sure that the words flagged by my macro were actually being used as intensifiers. (For example, the word "clear" was often used as part of a legal standard, such as "clear and convincing evidence.") I then eliminated those words from the count, and calculated an "intensifier per page" ratio for each of the briefs. The Thomas More Center and Liberty University briefs rang up 1.25 and 1.22, respectively, intensifiers per page, while the Mead v. Holder brief scored only 0.65 intensifiers per page. The United States briefs in those three cases scored, respectively, $0.18,0.73$, and 0.45 intensifiers per page.

77 Pl. Mot. for a Prelim. Inj. \& Brief in Support, Thomas More Law Ctr. v. Obama, 2010 WL 4784264 at 12.

78 For example, the plaintiffs' brief argues that the government's position

defies common sense. More importantly, it does not create the necessary nexus between an individual's economic activity and interstate commerce. This socialist mentality would allow Congress to nationalize anything on the assumption that all must pay in order to make the object of regulation affordable to all.

Pl. Brief in Opposition to Mot. to Dismiss, Liberty University v. Geithner, 2010 WL 4850338 at 16.

79 It may be a bit misleading to characterize these cases as having been filed on behalf of state governments, of course, since it is often difficult to decide who speaks on behalf of the state. All of the "states" that signed on to one of the two cases in this 
Commerce Clause issue, rather than State Government Stories standing. ${ }^{80}$ They are summarized in the sidebar "State Government Stories." The main case in this group is Florida ex rel. Bondi v. U.S. Dept. of Health and Human Services, a case ultimately joined by twenty-six state Attorneys General. ${ }^{81}$ A second case, Virginia ex rel. Cuccinelli v. Sebelius, was brought solely on behalf of the Commonwealth of Virginia by its Attorney General.82 Both cases tell similar stories on behalf of the plaintiffs.

Protagonist(s) State governments. Hero type: Ruler.

Goal(s) Not to increase spending on health care; protect state police power from federal usurpation

Obstacle(s) (1) Systemic (Act coerces states to behave in ways acceptable to the federal government); (2) Antagonist (Congress as Threshold Guardian)

\section{Protagonist}

The selection of a heroic archetype for the State plaintiffs is fairly straightforward: they take on the role of Ruler heroes. The goal of a Ruler is to "create a prosperous family or community, and to gain power." 83 The chief task of a Ruler hero is to take responsibility, for himself or herself or for others. ${ }^{84}$ The briefs in both cases are clearly about preserving state power, allegedly to protect the members of their community (state citizens) from the overreaching federal government. The states claim the responsibility for insuring the welfare of the citizens within their borders.

\section{Goal}

Both of the cases in this group tell essentially a "states' rights" story. Both briefs invoke the Framers and the original intent of the Commerce Clause of the United States Constitution. ${ }^{85}$ Both briefs argue that the PPACA, if it were allowed to coerce citizens to purchase insurance, would create an almost unlimited federal police power, correspondingly decreasing the power historically considered to be exclusively exercised by states. The

group were added to the litigation on the authority of the elected Republican state attorney general, even though in some cases the state governor and one or more of the houses of the state legislature were controlled by Democrats, who may not have agreed with joining their state as a plaintiff in this litigation.

80 The United States raised the standing issue in both cases, but lost: Florida ex rel. Bondi v. Dept. of Health and Human Services, 780 F. Supp. 2d 1256, 1271 (N.D. Fla. 2011); Virginia ex rel. Cuccinelli v. Sebelius, 702 F. Supp. 2d 598, 607 (E.D. Va. 2010).

81 See 780 F. Supp. 2d at 1262-63 (listing plaintiffs). Two individual plaintiffs and an association representing business interests also joined as plaintiffs, although the brief on behalf of the Plaintiffs barely mentions them at all; they appear to be "fail safe" plaintiffs designed to insure that some plaintiff had standing to bring the lawsuit.
82 See 728 F. Supp. $2 d$ at 770.

83 Robbins, supra n. 19, at 803.

84 Pearson, supra n. 26, at 183.

85 The brief in Florida ex rel. Bondi v. U.S. Dept. of Health and Human Services makes a passing reference to the original intent: 'If this had been the Framers' intent, and if this is the Constitution's meaning, then all of the remaining provisions of Article I, section 8 demarcating Congress's specific authority would be 'mere surplusage." Memo. in Support of Pl. Mot. for S.J., 2010 WL 4564355 at 15 The brief in Virginia ex rel. Cuccinelli v. Sebelius is much more expansive, including an entire section devoted to the historical context in which the Commerce Clause was drafted, including a citation to the Federalist Papers. Pl. Memo. in Support of Mot. for S.J., 2010 WL 3536788 at 10-11 (E.D. Va., Sept. 3, 2010). 
Commonwealth of Virginia's brief (at least as far as it relates to the Commerce Clause issue) is exclusively devoted to a discussion of the boundary between the power of the states and the power of the federal government; its statement of the undisputed facts also points out that the Virginia legislature enacted, and its governor signed, a law providing that no citizen of the Commonwealth could be compelled to purchase health insurance except in specified, and limited, circumstances. ${ }^{86}$ The Plaintiffs' brief in Florida ex rel. Bondi v. U.S. Dept. of Health and Human Services is similarly protective of states' right to decide what is best for their citizens $;{ }^{87}$ it also includes a section claiming that the PPACA would force states to incur "substantial costs and obligations to cover millions more Americans through a fundamentally transformed Medicaid program." 88

Thus, the goal of the state plaintiffs is simply preservation of their rights as Rulers against the competing claim of a different Ruler (the federal government).

\section{Obstacle}

The obstacles in this story are similar to those in the stories told by the physicians and the private individuals. The principal obstacle is systemic: the PPACA itself. But Congress also appears fairly clearly in the role of antagonist as well. These briefs are not immune from the occasional hyperbolic claim, ${ }^{89}$ but they do not sound as histrionic as some of the briefs filed by the private plaintiffs. ${ }^{90}$ And because the Florida brief, in particular, acknowledges a legitimate role for Congress in health-care funding, ${ }^{91}$ it appears that the States have taken a more nuanced, and reasonable, view of Congress as antagonist. Rather than characterize Congress as a pure Villain, the states appear to cast Congress as a

86 Pl.'s Memo. in Support of Mot. for S.J., Virginia ex rel. Cuccinelli, 2010 WL 3536788 at 7-8. The circumstances under which a person could be compelled to purchase health insurance primarily involve court or administrative proceedings, or situations in which college students are required to obtain and maintain health insurance as a condition of enrollment. Id. at 7.

87 In pointing out that Congress explicitly invoked the example of the healthcare law adopted in Massachusetts, which also includes an individual mandate, plaintiffs note wryly that

Congress's open emulation of a State police-power regulation is telling. In enacting the Individual Mandate, Congress is attempting to exercise the very plenary power that the Constitution forbids it.

Memo. in Support of Pl. Mot. for S.J., 2010 WL 4564355 at 16.

$88 \mathrm{Id}$. at 20
89 For example, the brief in Florida ex rel. Bondi v. U.S. Dept. of Health and Human Services claims that the Commerce Clause power that Congress claims in enacting PPACA is "unbridled," "novel and sweeping;" and that the new Medicaid regime would cause "devastating consequences to [states'] already-strained budgets." $I d$. at 8 . It further described the new, broader federal program as imposing "crushing new costs" on the states. Id. at 21.

90 The "intensifier ratio" for the Virginia ex rel. Cuccinelli v. Sebelius brief was 0.78 , and for the Florida ex rel. Bondi v. U.S. Dept. of Health and Human Services it was 1.17. Both of these scores were still higher than the corresponding briefs on behalf of the United States: 0.29 and 0.28 , respectively.

91 See Memo. in Support of Pl. Mot. for S.J., 2010 WL 4564355 at 20 (emphasis in original) ("Medicaid was the hallmark of cooperative federalism, a true partnership, when the States joined the program in the 1960's and 1970's." Id.). 
Threshold Guardian: not purely evil, but simply a character whose objective was different from that of the protagonist.

\section{The United States government story}

Whereas the stories told by the plaintiffs varied among these three groups of plaintiffs-because there were different protagonists in each story-the United States told essentially the same story in all cases, which is summarized in the sidebar "United States Government Story."

\section{Protagonist}

The United States tells a more complex story than any of the plaintiffs do. It cannot deny its basic persona as a Ruler hero: it is attempting to create a pros-

United States Government Story

Protagonist(s) (1) The United States government, acting benignly on behalf of all citizens. Hero type: Ruler.; (2) All American citizens. Hero type: Everyperson

Goal(s) Affordable health care for all citizens

Obstacle(s) (1) Systemic (health care system); (2) Antagonists (various Threshold Guardians, including private insurers who cherry-pick the healthiest patients and freeloaders who don't buy insurance and then rely on charity care from health care providers, who then pass the cost of that care back to Everyperson) perous community for all citizens by creating a new system that provides affordable healthcare for all. But, no doubt mindful of the plaintiffs' attempt to paint the federal government as a big, bad bully, the attorneys for the United States also cast all American citizens in the role of coprotagonist, or at least a companion character. After all, a Ruler's job is to protect his family or community; thus, all of the briefs filed by the United States do a good job of putting the people it protects (the Everyperson hero, all American citizens) into the center of the story. In this regard, the United States' briefs are more nuanced than those filed by the other contestants for the mantle of Ruler, the state governments. The states' briefs make infrequent references to their own citizens and seem to characterize this dispute as a more personal fight between the United States and the state governments themselves.

\section{Goal}

The United States has also chosen a goal that nobody can reasonably argue with. There is little dispute that healthcare in this country is allocated in ways that favor the wealthy and that leave many people of modest means with inadequate or no health insurance. Fair-minded people would likely wish that healthcare be more universally available, and at a lower cost. Although this is a worthy goal for a benign Ruler, given the ascendancy of antigovernment sentiment among a segment of the population, it is not surprising that the government chose to downplay its 
own role in securing that goal, and to put its companion character, Everyperson, at the center of its story.

\section{Obstacle}

The United States also does a good job of depersonalizing the obstacle it is trying to overcome. Most of the briefs filed by the United States begin by depicting a health-care system that is badly broken, in which insurance companies pick and choose who they will cover, and which leaves 45 million Americans without basic health insurance. ${ }^{92}$ It describes this situation as unfair because "virtually no individuals can make a personal choice to eliminate all current or potential future consumption of healthcare services."93 But it points out that, because federal Medicare law requires hospitals with emergency rooms to treat and stabilize every patient who presents, regardless of his or her ability to pay, uninsured people don't go without healthcare. They simply get free (or "charity") care at the nearest hospital emergency room. ${ }^{94}$ The hospital then recovers the cost of that care by a practice known as "cost shifting," in which it overcharges insured or self-pay patients in order to generate funds to provide free care to uninsured patients. ${ }^{95}$

In this story, all citizens are depicted as protagonists, deserving of reasonably priced and universally available healthcare. The antagonists include the greedy ${ }^{96}$ insurance companies who seek to "exclude from coverage those they deem most likely to incur expenses." ${ }^{97}$ The solution to the problem, according to this story, is to require insurance companies to cover everybody, without imposing an exclusion for preexisting conditions, and to require everybody to share the cost. Thus the so-called "individual mandate," which requires everybody to purchase insurance (on pain of a tax penalty if they do not), creates the largest possible risk pool

92 Despite the fact that insurance companies have potentially the most at stake in healthcare reform, none of the cases in the study group were brought by insurance companies. Perhaps because, as some commentators have noted, the bill that actually passed may benefit insurance companies in the long run, by increasing the number of people who purchase insurance. See Ken Terry, CBS Money Watch, Big Winner in Healthcare Reform? Insurance Companies, Eventually (March 22, 2010) (available at http://www.bnet.com/blog/healthcare-business/big-winner-in-healthcare-reform-insurance-companies-eventually/1267).

93 Memo. in Support of Def. Mot. for S.J., Florida ex rel. Bondi v. U.S. Dept. of Health and Human Services, 2010 WL 4564357 at 12 (N.D. Fla., Nov. 4, 2010). Not all of the many briefs filed by the United States contain extensive recitations of the facts, since apparently some of the trial courts requested the parties submit a joint statement of the record. The brief that probably contains the most complete recitation of the facts of the case from the United States' point of view is its brief in the Florida ex rel. Bondi v. U.S. Dept. of Health and Human Services case; thus, the representative examples I draw upon in this section of the article are all from that brief.

94 Id. at 12 .

95 Id. at 14 .

96 My word, not the United States'.

97 Id. at 13. 
over which to spread the risk of health-related expenses. By not allowing people to wait until they actually need healthcare to purchase insurance, premiums for everybody will be lower because more people are sharing the costs.

By telling this complex story, the United States appears to be facing reality. The story rings true. ${ }^{98}$ There is no effort to demonize insurance companies: while the briefs generally include a section describing insurance industry practices such as "cherry-pick[ing]" healthy patients while denying coverage to those who are not as healthy, and denying coverage for pre-existing conditions, ${ }^{99}$ they do so by reciting facts in a fairly neutral manner. ${ }^{100}$ There is an implicit understanding that insurance companies are for-profit enterprises, simply participating in the free market, as is their legal right. Indeed, the tone of the government briefs is, on the whole, much more subdued than that of any of the plaintiffs. ${ }^{101}$ Accordingly, it appears that the government has cast the antagonists in its story as Threshold Guardians: simply characters with understandable (and legal) objectives that are at odds with the government's more important objectives (the protection of Everyperson).

\section{The Winners and the Losers}

Whereas these twelve cases raised a variety of legal issues, the only two issues that resulted in final dispositions of any of the cases were whether the plaintiffs had standing to sue and whether PPACA is a valid exercise of Congress' power under the Commerce Clause. Might the stories allied with the parties' archetypal roles have influenced the court's decision in each of those cases?

\section{A. The standing cases}

Six of the twelve cases in this study were resolved on the issue whether the plaintiffs had standing to sue. ${ }^{102}$ Five of the plaintiffs in that group were private individuals or employers; one was a group of physicians. None of

98 It thus satisfies the reader's desire for what Prof. Rideout describes as "narrative fidelity." See generally Rideout, supra n. 10. 99 See e.g. Memo. in Support of Def. Mot. for S.J., Florida ex rel. Bondi v. U.S. Dept. of Health and Human Services, 2010 WL 4564357 at 13.

100 For example, the brief cites statistics compiled by the nonpartisan Congressional Budget Office regarding the number of uninsured Americans, various scholarly articles regarding consumer behavior, and testimony before Congress from various scholars. Id. at 12-13.

101 The average "intensifier ratio" for all of the United States briefs in the Commerce Clause cases was 0.36; the average ratio for all of the Plaintiffs' principal briefs in those same cases was 1.02, or nearly three times higher.

102 See supra Table 1. 
the cases brought by state governments was dismissed at the trial level for lack of standing. ${ }^{103}$

\section{Physicians vs. United States}

The physicians lost. Their story-"we like our business model the way it is"-apparently did not resonate with Judge Wigenton in quite the way that the "we're all in this together" story of the United States did. Their story was essentially that the physicians were comfortable with the existing business model for practicing medicine and did not want anything to change. ${ }^{104}$ This case was dismissed by the trial judge on the basis that the plaintiffs lacked standing to sue. ${ }^{105}$

It is not hard to imagine why the government's story of "we're all in this together" was more effective. In a contest between well-educated and highly-paid physicians and the American Everyperson-who is lucky if he has health insurance at all, much less adequate coverage-Everyperson is going to be the more sympathetic protagonist. Moreover, since the physicians did a poor job of explaining what potential negative impact the law would have on them (i.e. they didn't tell a very good story), it is not surprising that the court found plaintiffs did not have a "concrete and particularized" injury, i.e., one "actual or imminent, not conjectural or hypothetical," 106 sufficient to maintain standing. In fact, the court suggested openly that it simply didn't believe the physicians' story:

\footnotetext{
Plaintiffs allege that Dr. Criscito has standing because the Act will affect "the manner in which he may, or may not seek payment for his professional services and the manner in which he may render treatment to his patients." According to Plaintiffs, Dr. Criscito will be unable to accept direct payments from his patients once the Act is effective. However, this argument has no basis. The Act does not prohibit Dr. Criscito or any physician from accepting direct payments from their patients. . . Additionally, the Act does not specify how physicians should render treatment to their patients. ${ }^{107}$
}

Thus, one can reasonably attribute the plaintiffs' failure in this case to their failure to tell a good enough story: the protagonist was less appealing, the goal was not sufficiently worthy, and the obstacle was not real.

103 However, one of the state cases was reversed on appeal and dismissed on the basis that the Commonwealth of Virginia lacked standing to sue. Virginia ex rel. Cuccinelli $v$. Sebelius, 656 F.3d at 272-73.

104 See supra Table IV.
105 The trial court's ruling was affirmed on appeal. $N$. $J$. Phys., Inc. v. Obama, 653 F.3d 234 (3d Cir. 2011).

106 See N. J. Phys., Inc. v. Obama, 757 F. Supp. 2d at 507. $107 \mathrm{Id}$. at 510 (internal citations omitted). 


\section{Individuals and employers vs. United States}

The five private individual-employer cases had mixed results. ${ }^{108}$ In three cases, the courts granted the motion by the United States to dismiss the case due to lack of standing, ${ }^{109}$ while in two cases the motion was denied. ${ }^{110}$ Yet the United States also raised the standing issue in the four private-plaintiff cases (as well as the two state-plaintiff cases), in which the court did reach the Commerce Clause issue. The courts necessarily found standing in all four of those cases-else they could not have decided the Commerce Clause issue. ${ }^{111}$ Thus, the final "scorecard" for the standing issue, when litigated in the context of private individuals or employers, was six private-plaintiff cases finding standing, and three not.

Why this occurred is difficult to puzzle out. Though the mainstream media has focused on the political affiliation of the judges deciding the cases on the Commerce Clause issue, suggesting political motivation, ${ }^{112}$ this explanation does not account for the cases decided on the standing issue. Of those six cases, plaintiffs were found to lack standing in four, and to have standing in two. ${ }^{113}$ Three of the four judges who dismissed the cases due to lack of standing were appointed by Republican Presidents, which does not fit the political explanation for how these cases were decided. In addition, one of the judges who found standing in this group of six was appointed by a Democratic President. Thus, four of the cases resolved on the standing issue do not seem to fit the supposed political "pattern."

Moreover, three judges appointed by Democratic Presidents reached the Commerce Clause issue, necessarily finding that the plaintiffs had standing (again running counter to the political explanation). Together with the four judges who ruled on the standing issue, in seven of the twelve cases studied, the rulings on standing seem contraindicated by the metric of which party's President appointed the judge. ${ }^{114}$

108 See supra Table I.

109 Baldwin v. Sebelius, 2010 WL 3418436 at 5; Shreve v. Obama, 2010 WL 4628177 at 7; Butler v. Obama, 814 F. Supp. 2d at 242.

110 U.S. Citizens Assoc. v. Sebelius, 754 F. Supp. 2d at 910; Bryant v. Holder, 2011 WL 710693 at 13.

111 See Thomas More Ctr v. Obama; Mead v. Holder; GoudyBachman v. U.S. Dept. of Health and Human Services.

112 I.e., the cases the United States won were decided by judges appointed by a Democratic president, whereas the cases won by the plaintiffs were decided by judges appointed by a Republican president. See supra Table 1; see also Kevin Sack, Round 1 in Appeals of Health Care Overhaul Goes to Obama, N.Y. Times, A15 (June 20, 2011) ("In various cases at the lower District Court level, five judges have divided on the question, with three Democratic appointees backing the law and two Republican appointees rejecting it.")
113 See supra Table 1.

114 Although my study was limited to the trial court opinions, in the one standing case that has been decided to date on appeal, this political bias explanation did not work, either. In N. J. Phys., Inc. v. Obama, a unanimous three-judge panel affirmed the dismissal of the case for lack of standing. 653 F.3d at 241. Two of the judges on that panel (Chagares and Jordan) were appointed by Pres. George H.W. Bush, which of course would be contraindicated if party politics had really made a difference. This is not to suggest, however, that the political affiliation of the President who appoints a judge is a reliable proxy for the political inclinations of the appointee; I make this observation merely to debunk the metric that most mainstream media commentators have used.

115 Lujan v. Defenders of Wildlife, 504 U.S. 555, 560 (1992). 
A better explanation for the results in the standing cases is probably that they are simply much more fact-bound than the cases decided on the merits of the Commerce Clause issue. A particular plaintiff has standing to sue only when he has "suffered an injury in fact-an invasion of a legally protected interest which is (a) concrete and particularized, and (b) actual or imminent, not conjectural or hypothetical."115 Since this standard requires a close examination of the facts peculiar to each plaintiff, it is hard to compare standing cases to each other. ${ }^{116}$

\section{B. The Commerce Clause cases}

The results in the six cases decided on the merits of the Commerce Clause issue were much more consistent. All of the state attorneys general won, and all but one ${ }^{117}$ of the private plaintiffs lost. But these results seem completely counterintuitive: since all of the cases challenged something called the "individual mandate," wouldn't the individuals have a more compelling story to tell as to how they have been injured?

What happened here? The Commerce Clause issue is a pure question of law. All the parties had the same case law and the same arguments available to them, and they all basically cited the same cases and made the same arguments. One significant variable in the Commerce Clause cases is the narrative argument.

There are certainly multiple possible reasons why these cases came out differently. These cases do break down neatly along political lines: the three judges appointed by Democratic presidents found the law constitutional, while the two judges appointed by Republican presidents found the law unconstitutional. ${ }^{118}$ But given that the standing issue did not break

116 The standing issue did not break nicely according to the type of plaintiff. Of the six cases shown in Table 1, supra, that were decided on the standing issue, five were filed by private individuals or companies (the lone exception being N. J. Phys. Assoc. v. Obama). In three of those cases, the private plaintiffs were found to lack standing, while in the other two standing was found. This reinforces the conclusion that these decisions were more likely based on the individual facts presented by each of the different plaintiffs or groups of plaintiffs.

117 The exception was Goudy-Bachman v. Dept. of Health and Human Services, which was decided after several of the Courts of Appeals had issued their rulings in other cases. See supra Table 1. A possible explanation for this outlier case is discussed in note 145, infra.

118 See supra n. 115 and accompanying text. Yet this pattern has broken down in all of the Courts of Appeals decisions that reached the merits of the Commerce Clause issue. In Thomas More Law Ctr v. Obama the panel affirmed by a 2-1 vote the trial court's decision that the PPACA was constitutional. 651 F.3d at 549. One of the judges in the majority (Sutton) was appointed by Pres. George H.W. Bush. In Florida ex rel. Bondi v. U.S. Dept. of Health and Human Services, the panel affirmed by a $2-1$ vote the trial court decision that the law was unconstitutional. $648 \mathrm{~F} .3 \mathrm{~d}$ at $1282-320$. One of the judges in the majority (Hull) was appointed by Pres. Clinton. In the third case, Seven-Sky v. Holder, 661 F.3d 1, 15-20 (D.C. Cir. 2011), the panel affirmed by a $2-1$ vote the trial court's decision that the law was constitutional. One of the judges in that majority (Silverman) was appointed by President Reagan; in addition, Judge Kavanagh (appointed by President George H.W. Bush) would have declined to reach the merits and dismissed the case because he believed the suit contravened the Anti-Injunction Act. Id. at 21 .

The Fourth Circuit did not reach the Commerce Clause issue in either of the cases it decided on appeal. In Virginia ex rel. Cuccinelli v. Sebelius, the court unanimously vacated the trial court's holding that the PPACA contravened the Commerce 
along political lines, ${ }^{119}$ and also because the judges themselves most likely would deny that politics had anything to do with their decisions, it is useful to consider other possible explanations. One such possibility is that the different stories told by the parties affected the judges in different ways. Since the defendant told essentially the same story in all of the cases and the plaintiffs told different stories (depending on who the client was), the differences in the stories may explain why some plaintiffs succeeded and why others did not.

\section{The private individuals' stories}

All but one of the private individuals and employers eventually lost. Of the eight cases, three were dismissed for lack of standing ${ }^{120}$ and three others were dismissed on summary judgment when the trial judges concluded that the statute was constitutional. ${ }^{121}$ In one case, the trial court ultimately ruled that the PPACA violated the Commerce Clause. ${ }^{122}$

In the seventh case, in which the trial court concluded that the PPACA violated the Commerce Clause, the private individuals presented themselves as Outlaw heroes, railing against the villainous Congress. ${ }^{123}$ Theirs was a story of rugged individualism. The protagonists all wanted to be left alone, free from government interference. They were self-reliant individuals who would choose their own method for paying for any healthcare they might need, thank you very much.

Although the United States presented itself as a Ruler hero, the focus of the brief was not on its power to protect. Instead, the brief focused on the needs of the government's companion, the American citizens (portrayed as an Everyperson hero). The Everyperson story actually works quite well to counteract the "Rugged Individual" story. In the government's story, everybody (including the Rugged Individuals) will need healthcare at some point. The larger the pool of people working together to carry that burden, the lighter the burden will be on everybody. By opting out of that pool, the Rugged Individuals are forcing Everyperson to carry more of the burden, all the while leaving the Rugged Individuals with the option of

Clause and instead ruled that the Commonwealth of Virginia lacked standing to sue. 656 F.3d at 273. In Liberty University v. Geithner, the same panel vacated the trial court's ruling that the Act was constitutional and instead ruled 2-1 that the suit was barred by the Anti-Injunction Act. 671 F.3d at 401-15. Judge Davis dissented from that holding, but would have ruled the PPACA to be constitutional. 671 F.3d at 422-52. All three judges on that panel were appointed by Democratic Presidents.

119 See supra sec. IV.A.2.

120 See supra Table 1.

121 Id.

122 See id. In the eighth case, the court concluded that the plaintiffs had standing to sue, thereby retaining jurisdiction of the matter, but no final disposition has yet occurred.

123 See supra sidebar Individual and Employers' Story. 
jumping into the insurance market at the moment they need care (since the law prohibits insurance companies from denying coverage for preexisting conditions). This combination of the initial refusal to share the burden common to Everyperson and the ability to reap the benefits of the law effectively portrays the Rugged Individuals as freeloaders. So the Outlaw story becomes unappealing: the goal of the Rugged Individuals is not worthy (or at least less worthy than the goal of the Ruler and Everyperson: affordable healthcare for all). The Rugged Individuals turn out to be part of the problem that the government describes.

Yet the government portrays the Rugged Individuals not as villains, but merely as threshold guardians. The briefs do not claim there is anything evil or immoral about the Plaintiffs' goal; it is simply in conflict with the more important goal shared by so many more people. Thus, the government's story seems to fit reality: it is plausible and nuanced. The protagonists and antagonists behave in ways that appear to be normal and easily understood. And the outcome has a certain Mr. Spock-like logic to it: the needs of the many outweigh the needs of the few. ${ }^{124}$

\section{State Governments vs. the United States}

The United States prevailed in all of the lawsuits brought by private individuals. The only two cases that resulted in victories for the plaintiffs were the two cases filed by state governments. When all of the private lawsuits were unsuccessful, why were both of the state government cases successful? Was the fundamentally different story told by the state governments at least part of the reason?

The states told an appealing story of federalism and states' rights. In our constitutional form of government, the central government is supposed to be a government of limited power. The Constitution itself enumerates certain powers available to the federal government, but specifically provides that powers not delegated to the United States are retained by the States, or the people. ${ }^{125}$ One consequence of this scheme is that, whereas the states retain a general "police power" to protect the health and safety of their citizens, the federal government does not have such a broad power. This system likely results from the Founders' then-

124 In the movie Star Trek II: The Wrath of Khan, Mr. Spock sacrifices his life to effect a repair to the Starship Enterprise. In his dying moments after making the repair, the following exchange takes place between Spock and the ship's commander:

Spock: Don't grieve, Admiral. It is logical. The needs of the many outweigh ...

Kirk: ... the needs of the few. . .

Star Trek II: The Wrath of Khan (Paramount Pictures 1982) (dialogue available at http://www.imdb.com/title/ tt0084726/quotes).

125 U.S. Const. amend X. 
recent (and unpleasant) experiences with strong central governments far from the people. ${ }^{126}$

In these cases, then, the Everyperson story told by the United States actually plays into the hands of the plaintiffs. The plaintiff-states told a story in which a strong central government is something to be feared; then along came the United States to confirm the states' worst fears by saying, "We are here to represent everybody in the country." The federal government's story perfectly fits the image of the strong central power that the Founders fought a revolution to overthrow. The plaintiffs' goal of preserving the police power of the states is portrayed as worthy, and the federal government is successfully cast as the obstacle: a Threshold Guardian whose understandable goal nevertheless conflicts with the higher goal of protecting state autonomy.

\section{What Does It All Mean?}

So, what conclusions can be drawn about which strategies worked, and, more importantly, why those strategies worked?

\section{A. Story can provide both motivating and justifying arguments}

It is tempting to think of story as providing only a type of a norm-based motivating argument-as opposed to a rule-based, justifying argument. ${ }^{127}$ Depending on the rule, though, a story can also function to satisfy a test imposed by that rule. In that sense, story becomes part of the justifying argument. For example, a rule that requires a close examination of the facts of the case (for example, to determine whether specified factors are present or not, or how those factors should be weighed) may require the advocate to tell a compelling story. The standing issue in this case is a good example of that situation.

\section{B. If the issue is fact-sensitive, it is essential to tell a credible story}

If your path to success depends on having good facts, good storytelling is essential. The corollary, of course, is that you'll be penalized for bad storytelling.

126 Although this theme is not quite explicit in the briefs filed by the states, it is fairly inferred from the several (and sometimes extensive) references to the Founding Fathers, the history of the Commerce Clause, and the citations to the Federalist Papers. This almost subliminal reference to the Revolution is far more effective than the private plaintiffs' overt casting as Outlaws, probably because it works at such an unconscious level. 
The standing issue in these cases is an example of an issue that is factsensitive: whether any plaintiff has suffered a sufficiently concrete and particularized injury that is actual or imminent obviously depends on the facts. Many of the plaintiffs in this group of cases told plausible stories and won; those who did not, lost. The best example of a bad story was the claim by the New Jersey Physicians Association that the PPACA would prevent physicians from billing patients directly. The judge saw no evidence of that requirement in the PPACA, and in all likelihood this was the key flaw in the plaintiff's case. ${ }^{128}$

Interestingly, the one appellate court decision that reversed the trial court decision did so on the question of standing. In Virginia ex rel. Cuccinelli v. Sebelius, the trial court ruled that the Commonwealth of Virginia had standing to bring suit and that the PPACA was unconstitutional. ${ }^{129}$ Part of the court's rationale was that the Virginia legislature, like several other states, ${ }^{130}$ had enacted a version of the Health Care Freedom Act, which purported to exempt all citizens within the Commonwealth from having to purchase health insurance. The trial court reasoned that this Act, signed by the Virginia governor the day after President Obama signed the PPACA, created a case or controversy between the state and the federal government as to whose law should apply. ${ }^{131}$ The Fourth Circuit, however, reversed, holding that the Commonwealth of Virginia is not subject to the individual mandate that it challenged in the lawsuit. Rather, the Commonwealth was seeking to assert claims held by its citizens as parens patriae and therefore lacked sufficient interest in the case to have standing. ${ }^{132}$

At first blush, this result may be somewhat difficult to reconcile with the United States' successful effort to put the Everyperson story about the need for equitable allocation of health-care resources at the center of its argument. Why should the United States be permitted to argue on behalf of Everyperson when the Commonwealth of Virginia could not? Most likely, this is a case of logos trumping the story: the Supremacy Clause of

128 See supra nn. 110-11 and accompanying text. The trial court thus concluded that the plaintiff lacked standing. Of course, another explanation for the result in this case was the lack of a sound legal argument, since the court found that the law did not require what the plaintiffs claimed it did. That is not so much a failure of the story as it is a failure of the logos based argument.

129 See Virginia ex rel. Cuccinelli v. Sebelius, 702 F. Supp. 2d 598, $602-07$ (E.D. Va. 2010) (determining standing to sue); Virginia ex rel. Cuccinelli v. Sebelius, 728 F. Supp. 2d at 772-78 (determining constitutionality).

130 One advocacy group has reported that, as of the time this article was written, twelve states had enacted either statutes or amendments to the state Constitution that purported to guarantee to the state's citizens the right to refuse to purchase healthcare insurance. See American Legislative Exchange Council, Health Care Freedom Initiative (available at http://www.alec.org/initiatives/health-care-freedom-initiative).

131 Virginia ex rel. Cuccinelli v. Sebelius, 702 F. Supp. 2d at 605-06.

132 Virginia ex rel. Cuccinelli v. Sebelius, 656 F.3d at 269. 
the United States Constitution bars attempts by state governments to nullify federal laws. ${ }^{133}$ Not even a good story can overcome settled law.

\section{If the issue is law-sensitive, storytelling still matters}

This conclusion is a bit counterintuitive. If the issue is one of pure law, wouldn't logic-based reasoning be all that is required? And wouldn't a judge, trained to resist emotional appeals and faithfully pledged to decide impartially upon an evenhanded application of neutral principles of law, distrust a story's inherent appeal to pathos?

If rule-based reasoning were all that mattered, however, all five of the Commerce Clause cases would likely have been resolved in the same manner. All five judges analyzed the same cases, and the arguments made by the parties on this issue were similar. One could therefore argue that some of the five judges just got it "wrong" while the others got it "right." However, lacking any reliable metric for evaluating a judge's competence, assume that all five judges are equally competent to read and understand the controlling case law. A more satisfying answer would be that this case falls within what Judge Richard Posner calls the "open area" of cases: that category of cases for which a legalistic examination of the applicable rules of law does not yield a "tolerable" answer. ${ }^{134}$ That issue is purely one of law: the same Commerce Clause applies in all five cases, and all five cases were brought against the same defendant (ultimately, the United States government). What is different in the five cases is the story told by the two different groups of plaintiffs in these cases. Here, the stories told by the parties serve as a motivating argument to supplement the justifying argument based on the Commerce Clause. The private plaintiffs' story was effectively countered by the story told by the United States government; the states' story was not.

Of course, the different stories were not the only way in which these cases differed. The private plaintiffs tended to be more strident in their rhetoric and more aggressive in attempting to portray the defendants (principally Congress) as villains. But portraying the protagonists' obstacle as a villain instead of some lesser antagonist is a storytelling choice. Judges are reasonable persons and are trained to be highly skeptical readers. Choosing an unrealistic, villainous role for the defendant-antagonist is

134 See Richard Posner, How Judges Think 9 (Harvard U. Press 2008). Most of the rest of Judge Posner's book reflects his attempt to describe how judges navigate the "open area." Some of the tools that may help a judge decide a case in this "open area" include "emotion, personality, policy intuitions, ideology, politics, background, and experience." Id. at 11. It is within Posner's "open area," I submit, that narrative reasoning has something valuable to offer the judicial process, since narrative can appeal to all of the tools that Posner thinks are used to decide such cases. 
likely to raise a great deal of skepticism and therefore is probably not an advocate's best choice.

\section{Ethos matters, too}

All the plaintiffs argued that the rationale advanced by the United States in support of PPACA would create a virtually unlimited federal power to regulate anything it wanted to. ${ }^{135}$ When that argument was advanced by private plaintiffs, it was rejected; when advanced by state governments, it was successful.

It is certainly possible that this was a mere coincidence. However, it is equally possible, or perhaps more likely, that ethos played a role in these differing outcomes. The "unlimited federal power" argument is ultimately a states' rights argument: only the states have a general police power. Such an argument would likely be taken more seriously when advanced by state governments, since the states are protecting their own interests. The private actors could be viewed as simply seizing opportunistically on any argument they can think of to avoid a result they don't like. In short, the states have the credibility (ethos) to make the argument; the private actors, not so much.

The Fourth Circuit's decision in Virginia ex rel. Cuccinelli v. Sebelius is further evidence that ethos matters. ${ }^{136}$ In that case, the appellate court reversed the trial court's decision that the Commonwealth of Virginia had standing to sue on behalf of its citizens for an alleged injury (the individual mandate) that the citizens alone (and not the state) suffered. This presents the converse of the Commerce Clause decisions: only individuals could credibly challenge the individual mandate.

\section{E. The law and the story must fit together seamlessly}

Perhaps the most important lesson to draw from these cases is that the story must fit the legal theory.

Persuasion is like a double helix: one strand of logos wound tightly with a strand of narrative reasoning. ${ }^{137}$ But for this technique to create a viable "DNA" molecule, the two strands must complement each other in a natural way. If they don't fit together well, the persuasion won't work.

135 See Pl. Mot. for a Prelim. Inj. \& Brief in Support, Thomas More Law Center v. Obama, 2010 WL 4784264 at 12; Memo. of Points and Authorities in Support of Pl. Mot. for S.J., Mead v. Holder, 2010 WL 5827945 at 11-18; Pl. Brief in Opposition to Mot. to Dismiss, Liberty University v. Geithner, 2010 WL 4850338 at 16-17; Pl. Memo. in Support of Mot. for S.J., Virginia ex rel. Cuccinelli v. Sebelius, 2010 WL 3536788 at 13-14; Memo. in Support of Pl. Mot. for S.J., Florida ex rel. Bondi v. U.S. Dept. of Health and Human Services, 2010 WL 4564355, passim.

136 See discussion at n. 129-32, above.

137 See Chestek, Judging By the Numbers, supra n. 5, at 3-5. 
The briefs of the private plaintiffs illustrate this point well. The basic story (the narrative strand of reasoning) was simply this: We want to be left alone and don't want the government telling us what to do. The logos strand consisted of an argument that the Commerce Clause did not give Congress the power to compel individuals to purchase insurance. But that logos does not fit the story, since it does not prove that "government" can't compel individuals to purchase insurance. It proves only that the federal government cannot do so. The plaintiffs' legal theory leaves state governments free to compel individuals to purchase insurance, ${ }^{138}$ so the plaintiffs cannot achieve through this theory what their story suggests they really want.

The state governments' more limited claim, however, does fit the legal theory perfectly. Their story is that they want to protect their own prerogatives in caring for their own citizens. ${ }^{139}$ The Commerce Clause argument matches that goal. Little wonder, then, that the states won and the private individuals did not.

\section{F. The story must sound true}

One of the defining features of the stories told by the parties was their complexity. All the plaintiffs (both private and states) told fairly simple stories: the plaintiffs were pure and worthy protagonists, the defendants were evil antagonists (portrayed as Villains). The United States, however, told a much more nuanced and complex story. For example, the story of the United States included more characters, including the government's Everyperson companion protagonist (all American citizens) and a multitude of antagonists (insurance companies, health-care providers, freeloaders), all drawn as Threshold Guardians. The complex interrelationships among all these characters were fully explained. The goals of the protagonists were much more clearly and explicitly laid out than the goals of any of the plaintiffs in their own briefs.

Perhaps because the audience for these briefs was a judge (as opposed to a jury), this complexity seems to have paid off for the United States, at least in the private-plaintiff lawsuits. This may be because the judges understood that we live in a complex world and that they trusted the United States' briefs to be more-accurate portrayals of the problem of inequitable distribution of health-care services and the potential solution.

138 The state of Massachusetts does this for healthcare, see Mass. Gen. Laws Ann. ch. 111M (Supp. 2012), and every state does it for automobile insurance, see Lee R. Russ et al., Couch on Insurance vol. 7A, \$109:1 (3d ed., Thomson/West 2005).

139 There is a certain irony that the states' method of "protecting its citizens" in the healthcare arena is to do nothing themselves, but simply to allow the private market to do whatever its invisible hands feel is appropriate. The states' argument boils down to "protecting their citizens" by leaving them at the mercy of private actors. 
Professor Chris Rideout describes what he calls three features (or "properties") of narratives that can be psychologically persuasive: narrative coherence, narrative correspondence, and narrative fidelity. ${ }^{140} \mathrm{He}$ describes "narrative fidelity" as the audience's perception of whether the story "ring[s] true with the stories [the audience] know[s] to be true." 141 Stated another way, narrative fidelity requires the audience to evaluate whether the stories they hear "represent[] accurate assertions about social reality and thereby constitutes good reasons for belief or action." 142 Because the story told by the United States about the complex healthcare-finance system was well-supported with factual authority and likely corresponded with judges' preexisting knowledge of how the health-care system works, it likely "rang true" to the audience's ears and thus reflected good "narrative fidelity."

But why did that work only in the case of the private plaintiffs? The United States told the same complex story in the two cases filed by state governments, but lost those two cases. The United States' loss may have been because the states were able to make the story be about something other than health-care finance.

The private plaintiffs played on the same field as the United States: the case was about health-care finance, and the story told by the United States had more narrative fidelity. The states, however, played on a different field: that of federalism. Their story was about power; specifically, in our federal system, which sovereign is permitted to make decisions about the welfare of its citizens? The case really wasn't about healthcare at all; it was just a power struggle, and they (the weaker states) needed the court's intervention to protect them from a much stronger adversary, the overreaching United States government. That story apparently had more "narrative fidelity" for the judges who heard those cases than the health-care finance story told by the United States.

\section{G. Audience matters, too}

Which recalls the initial question suggested by the media: Isn't it all about the political leanings of the judges who heard these cases?

In the cases brought by the states, the trial judges had competing narratives to choose from. ${ }^{143}$ The United States told a story about a dysfunctional health-care system, while the states told a story about a

140 Rideout, supra n. 10, at 55.

141 Id. at 70 (quoting Walter Fisher, Human Communication as Narration: Toward a Philosophy of Reason, Value, and Action 64 (U.S.C. Press 1989)).

142 Rideout, supra n. 10, at 70.

143 See supra sec. V.F. 
runaway federal government. The outcome of the case depends very much on which story the judge chose to listen to. ${ }^{144}$

Suppose the judge decided that the case was about the broken healthcare system. The states did not really dispute that in their briefs; their "solution" was completely laissez-faire: to let individuals make their own choices and to let the market decide. In that contest, the United States' complex and well-supported story about how the health-care system really works and how it leaves millions of people at risk for potentially catastrophic expenses is pretty compelling. The court would likely want to protect the weak Everyperson companion and rule in favor of the United States.

But the two judges who heard the state government cases instead viewed the dispute as one of federalism: should the federal government's power extend as far as the PPACA seems to push it? In Virginia ex rel. Cuccinelliv. Sebelius, the United States filed a Motion to Dismiss on several grounds, including claims that the Commonwealth of Virginia lacked standing to sue, that the controversy was unripe, and that since the PPACA was enforced through a tax measure, the suit was barred by the Anti-Injunction Act. ${ }^{145}$ The trial court rejected all of these claims ${ }^{146}$ and instead decided the matter on competing Motions for Summary Judgment. ${ }^{147}$ In framing the issue before it, the trial court first acknowledged the federalism story told by the state by reporting that the Commonwealth was attempting to protect its sovereignty from encroachment by Congress, invoking the Tenth Amendment. ${ }^{148}$ But the court began its recitation of the United States' version of the story (which told of the broken health-care system) by saying, "The Secretary prefaces her response with an acknowledgment that the debate over the constitutionality of the $[\mathrm{PP}] \mathrm{ACA}$ has evolved into a polemic mix of political

144 In fairness, the courts that decided the private-plaintiff cases also had a choice of which story to listen to. In the one private-plaintiff case in which the trial judge determined that the PPACA violated the Commerce Clause, the opinion began by framing the issue in terms of the federalism story:

As a threshold matter, I emphasize, as Judge Vinson emphasized in Florida v. U.S. Department of Health \& Human Services, [citation omitted], that this case is not about whether the Health Care Act merely treats the symptoms or cures the disease which has so clearly afflicted our health care system. Nor is it about the exhaustive efforts of Congress to document and to project the increasing costs of health care services or to pinpoint discriminatory practices associated with pre-existing conditions.

Rather, this case concerns the precise parameters of Congress's enumerated authority under the Commerce Clause of the United States Constitution. Specifically, the issue is whether Congress can invoke its Commerce Clause power to compel individuals to buy insurance as a condition of lawful citizenship or residency.

Goudy-Bachman v. U.S. Dept. of Health and Human Services, 811 F. Supp. 2d at 1089.

145 Memo. in Support of Def. Mot. to Dismiss, 2010 WL 2315702 (May 24, 2010).

146 Virginia ex rel. Cuccinelli v. Sebelius, 702 F. Supp. 2d 598 (E.D. Va. 2010).

147 Virginia ex rel. Cuccinelli v. Sebelius, 728 F. Supp. 2d 768 (E.D. Va. 2010).

148 Id. at 772. 
controversy and legal analysis." ${ }^{49}$ There is little doubt from the way the court framed the competing stories as to which story the court heard most clearly. ${ }^{150}$

The trial court in Florida ex rel. Bondi v. U.S. Dept. of Health and Human Services was even more explicit about saying which story was important to it:

I emphasized once before, but it bears repeating again: this case is not about whether the Act is wise or unwise legislation, or whether it will solve or exacerbate the myriad problems in our health care system. In fact, it is not really about our health care system at all. It is principally about our federalist system, and it raises very important issues regarding the Constitutional role of the federal government.

James Madison, the chief architect of our federalist system, once famously observed:

\begin{abstract}
If men were angels, no government would be necessary. If angels were to govern men, neither external nor internal controls on government would be necessary. In framing a government which is to be administered by men over men, the great difficulty lies in this: you must first enable the government to control the governed; and in the next place oblige it to control itself. ${ }^{151}$
\end{abstract}

In the federalism story, it is the state governments who are weak and in need of the judge's protection; the judges provided that protection. So why did the judges choose to decide the case based on the federalism story told by the state governments instead of the health-care system story told by the United States?

149 Id.

150 My objective in this project was to study the differing trial court rulings in this nationwide litigation. But the story behind the case is interesting on the appellate court level, too. Whereas the trial judge in the Commonwealth of Virginia litigation heard the federalism story, the Fourth Circuit heard quite a different story, indeed. Since the trial judge's prior ruling denying the United States' Motion to Dismiss was an interlocutory order, the issues of standing, ripeness and the applicability of the Anti-Injunction Act were preserved for appeal and were heard along with the appeal on the merits of the Commerce Clause issue. The Fourth Circuit held that the Commonwealth of Virginia lacked standing to sue and therefore dismissed the action, vacating the trial court's decision on the merits. Virginia ex rel Cuccinelli v. Sebelius, 656 F.3d at 266-73. In so doing, the Fourth Circuit rejected the federalism story advanced by the Commonwealth, holding that the Virginia Health Care Freedom Act, adopted the day after the PPACA,

does not confer on Virginia a sovereign interest in challenging the individual mandate... [T] he VHCFA regulates nothing and provides for the administration of no state program. Instead, it simply purports to immunize Virginia citizens from federal law. In doing so, the VHCFA reflects no exercise of "sovereign power," for Virginia lacks the sovereign authority to nullify federal law.

Id. at 270. Why the Court of Appeals paid attention to a different story than did the trial judge is an interesting question but beyond the scope of this article.

151 Florida ex rel. Bondi v. U.S. Dept. of Health and Human Services, 780 F. Supp. 2d at 1263 (quoting The Federalist No. 51, at 348 (James Madison) (N.Y. Heritage Press ed., 1945)). 
Here is where the effect of the judges' preexisting worldviews cannot be denied. Since the judge gets to decide which story will provide the battlefield on which the contest is decided, a judge's inclination to favor one sort of story over another may prove decisive. That is to say, judges who are inclined to favor stories about rules and processes may choose to decide the cases based on the federalism issue; judges who favor stories about humans and their individual struggles may choose to decide the case on the broken health-care-system issue.

Judges, like other humans, have a variety of world-views. Some are conservatives, resistant to change; others are more liberal, accepting of change. Conservatives and liberals respond very differently to different stimuli. Stories featuring certain types of heroes told to somebody with a conservative world view will likely yield a very different reaction than the same story told to somebody with a more liberal world view. Stated another way, conservatives and liberals will understand the case, and choose the heroes they empathize with, differently.

But that doesn't mean that the judges' decisions are all about politics and that the outcome of a case is determined as soon as one type of judge or another is assigned to hear the case. What it does mean, however, is that the advocate needs to choose the story she tells carefully. More importantly, once she knows which judge has been assigned to hear a case, she needs to learn as much as she can about that judge's background and prior rulings, looking for evidence of what kinds of stories the judge responds to. Then she needs to carefully choose heroic archetypes for her client and to craft the story in such a way as to appeal to the judge's favored worldview.

I also don't mean to suggest any of the five trial court judges in this litigation consciously chose which story to listen to in order to decide the case in a way that favored their own political views. In fact, I very much doubt that they did; it is far more likely that the judges, at least consciously, believed that they were applying the law fairly and impartially to an agreed set of facts. But heroic archetypes are embedded deep within each of us; they work at the level of the unconscious. We usually cannot control which one gets triggered when we are exposed to different stimuli. The same stimuli may subconsciously evoke different heroic archetypes in different people, as they may in different judges. The advocate's difficult task is to try to determine which archetype a particular judge is most likely to see and to favor, then tell a story to evoke that archetype. 


\section{Conclusion}

Narrative reasoning likely has some effect in every case, and potentially a dispositive effect in cases wherein the rules of law don't readily yield a clear answer. Since reasonable minds may easily differ on the interpretation of the Commerce Clause and the precedents that have interpreted it, I contend that narrative reasoning likely played a role in the differing decisions reached by all of the judges who have handled these cases to date.

The stories that parties tell in their briefs are not all that helps to persuade a judge. Stories are important persuasive tools, but their effect is hardly the most important factor in every case. A case with a very powerful narrative will ultimately not succeed if the rules of law don't support the relief requested.

Not surprisingly, the United States Supreme Court has granted certiorari in this litigation. ${ }^{152}$ I do not wish to make any prediction here about how that case may turn out; in fact, the way that the Supreme Court hears and responds to stories is likely very different from how trial courts and Courts of Appeal respond to stories. ${ }^{153}$ My only bit of advice to the advocates who will argue that case is this: Stories matter.

\section{Appendix A}

Some scholarship that grew out of presentations at one of the Applied Legal Storytelling Conferences (as of September 2011) 154

\section{A. Law review articles}

Paula Abrams, We the People and Other Constitutional Tales: Teaching Constitutional Meaning Through Narrative, 41 The Law Teacher 247 (2007).

Michael Blissenden, Using Storytelling as a Teaching Model in a Law School: The Experience in an Australian Context, 41 The Law Teacher 260 (2007).

\footnotetext{
152 Petitions for certiorari were granted in several of the cases, including the major case in which twenty-six state attorneys general joined as plaintiffs: U.S. Dept. of Health and Human Services v. Florida, ___ U.S. __, 132 S. Ct. 604 (2011). A summary of the Supreme Court filings and their dispositions can be found at the Supreme Court official website, http://www.supremecourt.gov/docket/ppaaca.aspx (last viewed April 18, 2012). Oral arguments in the cases were heard over three days, from March 26 through 28, 2012; links to audio recording of those arguments can be found at the Supreme Court website, $i d$. A ruling is expected by June, 2012.

153 One respected scholar has described the Supreme Court as a "political court" and therefore attentive to different modes of persuasion than other courts. Posner, supra n. 135, at 269-323.

154 Thanks to Ruth Anne Robbins, one of the organizers for all three of the Applied Legal Storytelling conferences to date, for allowing me to reproduce this bibliography, which she first created. I have added a few more articles published since she first compiled this listing.
} 
Katerina P. Lewinbuk, Can Successful Lawyers Think in Different Languages? Incorporating Critical Strategies that Support Learning Lawyering Skills for the Practice of Law in a Global Environment, 41 The Law Teacher 275 (2007).

Anna P. Hemingway, The Ethical Obligations of Lawyers, Law Students and Law Professors Telling Stories on Web Logs, 41 The Law Teacher 287 (2007).

Robert McPeake, Fitting Stories into Professional Legal Education-The Missing Ingredient, 41 The Law Teacher 303 (2007).

Laura Spitz, Wands Away (or Preaching to Infidels Who Wear Earplugs), Law Teacher, 41 The Law Teacher 314 (2007).

Ruth Anne Robbins, An Introduction to Applied Legal Storytelling, 14 Leg. Writing 17 (2008).

Brian J. Foley, Applied Legal Storytelling, Politics, and Factual Realism, 14 Leg. Writing 17 (2008).

J. Christopher Rideout, Storytelling, Narrative Rationality, and Legal Persuasion, 14 Leg. Writing 53 (2008).

James Parry Eyster, Using Significant Moments and Obtuse Objects to Enhance Advocacy, 14 Leg. Writing 87 (2008).

Kenneth D. Chestek, The Plot Thickens: The Appellate Brief as Story, 14 Leg. Writing 127 (2008).

Elyse Pepper, The Case for "Thinking Like a Filmmaker": Using Lars von Trier's Dogville as a Model for Writing a Statement of Facts, 14 Leg. Writing 171 (2008).

Mary Ellen Maatman, Justice Formation from Generation to Generation: Atticus Finch and the Stories Lawyers Tell Their Children, 14 Leg. Writing 207 (2008).

Stacy Caplow, Putting the "I" in Wr"t"ng: Drafting an A/Effective Personal Statement to Tell a Winning Refugee Story, 14 Leg. Writing 249 (2008).

Patricia Grande Montana, Better Revision: Encouraging Student Writers to See Through the Eyes of the Reader, 14 Leg. Writing 291 (2008).

Laurie Shanks, Whose Story is it Anyway?-Guiding Students To Client-Centered Interviewing Through Storytelling, 14 Clinical L. Rev. 509 (2008).

Michael J. Higdon, Something Judicious This Way Comes .. . The Use of Foreshadowing as a Persuasive Device in Judicial Narrative, 44 U. Rich. L. Rev. 1213 (2010).

Kenneth D. Chestek, Judging by the Numbers: An Empirical Study of the Power of Story, 7 J. ALWD 1 (2010).

Carolyn Grose, Storytelling Across the Curriculum: From Margin to Center, from Clinic to the Classroom, 7 J. ALWD 37 (2010).

Steven J. Johansen, Was Colonel Sanders a Terrorist? An Essay on the Ethical Limits of Applied Legal Storytelling, 7 J. ALWD 63 (2010). 
Derek H. Kiernan-Johnson, Telling Through Type: Typography and Narrative in Legal Briefs, 7 J. ALWD 87 (2010).

Julie A. Oseid, The Power of Metaphor: Thomas Jefferson's "Wall of Separation between Church \& State," 7 J. ALWD 123 (2010).

J. Christopher Rideout, Penumbral Thinking Revisited: Metaphor in Legal Argumentation, 7 J. ALWD 155 (2010).

Deborah A. Schmedemann, Voice: Speaking for a Deaf Boy in Foster Care, 7 J. ALWD 203 (2010).

Helena Whalen-Bridge, The Lost Narrative: The Connection Between Legal Narrative and Legal Ethics, 7 J. ALWD 229 (2010).

Stefan H. Krieger \& Serge A. Martinez, A Tale of Election Day 2008: Teaching Storytelling Through Repeated Experiences, 16 Leg. Writing 117 (2010).

Jeanne M. Kaiser, When the Truth and the Story Collide: What Legal Writers Can Learn from the Experience of Non-Fiction Writers about the Limits of Legal Storytelling, 16 Leg. Writing 163 (2010).

Helen A. Anderson, Changing Fashions in Advocacy: 100 Years of Brief-Writing Advice, 11 J. App. Prac. \& Process 1 (2010).

Harriet N. Katz, Stories and Students: Mentoring Professional Development, 60 J. Leg. Ed. 675 (2011).

Ian Gallacher, Thinking Like Non-Lawyers: Why Empathy is a Core Lawyering Skill and Why Legal Education Should Change to Reflect Its Importance, 8 J. ALWD 109 (2011).

\section{B. Book chapters}

This section lists chapters of the book The Law \& Harry Potter (Carolina Academic Press 2010), all of which were presented at one of the first two Applied Storytelling conferences.

Mary Beth Beazley, Which Spell? Learning to Think Like a Wizard.

Eric J. Gouvin, The Magic of Money and Banking.

Sue Liemer, Bots and Gringotts: Anglo-Saxon Legal References in Harry Potter.

Heidi Mandanis Schooner, Gringotts: The Role of Banks in Harry Potter's Wizarding World.

Aaron Schwabach, Harry Potter and the Unforgiveable Curses. 
